\title{
Introduction: Georges Sorel's Study on Vico in French and European Context
}

Somewhere between late nineteenth century critics of bourgeois modernity, such as Friedrich Nietzsche, and exalted twentieth century militarists, such as Ernst Jünger and Benito Mussolini, is to be found Georges Sorel (1847-1922) at least according to the usual narratives of the period's intellectual history. The commonly accepted image of Sorel is that of a theorist of violence, a philosophical irrationalist, and a precursor of fascism. ${ }^{1}$ Sorel's work is taken as the paradigmatic representation of that late nineteenth century "crisis of reason" which anticipated and prepared the way for the tragedies of the first half of the twentieth century. ${ }^{2}$ It is, however, sufficient to scratch but the surface of this widely accepted image to see how it is disproportionately based on the reading of only one of Sorel's works, the 1908 Reflections on Violence.

1 See, amongst many such views, above all the works of Zeev Sternhell, such as Zeev Sternhell, Neither Right nor Left: Fascist Ideology in France, trans. David Maisel, 2nd ed. (Princeton, NJ: Princeton University Press, 1995), 68-81; Zeev Sternhell, Maia Asheri, and Mario Sznajder, The Birth of Fascist Ideology. From Cultural Rebellion to Political Revolution, trans. David Maisel (Princeton, NJ: Princeton University Press, 1994), 36-91; Jan-Werner Müller, "Myth, Law and Order: Schmitt and Benjamin Read Reflections on Violence," History of European Ideas 29 (2003): 459-473; George Douglas Howard Cole, A History of Socialist Thought. The Second International 1889-1914, vol. 3 (London: Macmillan, 1956), 382-387. Alternative and more nuanced readings of Sorel in English are available in Jeremy Jennings, Georges Sorel. The Character and Development of His Thought (Hong Kong: Palgrave Macmillan, 1985); John Stanley, The Sociology of Virtue. The Political and Social Theories of Georges Sorel (Berkeley, CA: University of California Press, 1981). See also the 1998 special issue of The European Legacy in memoriam John Stanley, including an essay from Stanley himself on Sorel and Vico, together with important work by Steven Vincent, Jeremy Jennings, Shlomo Sand, and Cécile Laborde. Among the older generation of English-language scholarship, James Meisel's Genesis of Georges Sorel (Ann Arbor, MI: George Wahr, 1951) ought to be mentioned, while H. Stuart Hughes' synthetic treatment in Consciousness and Society (New York: Vintage Books, 1958), 90-95 and 161-182, is also still valuable. Isaiah Berlin's 1971 essay on Sorel for all its limits, also still ranks as among the best short treatments: Berlin, Against the Current. As for the French historiography, the journal Mil neuf cent. Revue d'histoire intellectuelle (previously Cahiers Georges Sorel) is key: it is not only a space of scholarly reflection on Sorel, but also where previously unpublished material often appears. See the recent issue "Sorel méconnu," Mil neuf cent 32 (2014). For a recent account of Cold War Anglophone reception of Sorel, see Eric Brandom, "Violence in Translation: Georges Sorel, Liberalism and Totalitarianism from Weimar to Woodstock." History of Political Thought 38, no. 4 (2017): 733-763.

2 See for example John Burrow, The Crisis of Reason. European Thought 1848-1914 (New Haven, ст: Yale University Press, 2000), 142. 
Beyond this relatively well-known though often misinterpreted text, the vast majority of Sorel's writings remain unknown and unread, particularly by Anglophone scholars. It is thus the unfortunate, though unsurprising, result of this scholarly neglect that Sorel should be reduced to the hollow image of an apocalyptic prophet, and that, almost a century after his death, he remains un méconnu célèbre, a thinker much talked about in passing references but seldom effectively engaged with and understood. ${ }^{3}$ A more realistic understanding of Sorel opens the way for re-evaluation of the intellectual history of the years around 1900 as more than a station on the via dolorosa of reason that the first half of the twentieth century usually constitutes in liberal historiography.

The "Study on Vico," here published for the first time in English translation, is a remarkable antidote against this consolidated historiographical image. This text introduces the reader to fundamental, yet regularly unacknowledged or underplayed, concerns and contexts of Sorel's work as a whole. Seen from the perspective of his study on Vico, Sorel does not appear as a philosophical irrationalist and an apologist of violence for its own sake, but instead as an epistemologist of the social sciences and as a Marxist theorist of considerable insight and originality. The sustained reflection on the possibility of Marxism as a social science, a key theme not only of the study on Vico but also of Sorel's career more generally, gives us the elements required for developing a new and more historically accurate view of the "metaphysician of revolutionary syndicalism," as Jean Jaurès once labelled him.

Beyond this re-interpretation of Sorel's work, the "Study on Vico" is of interest for at least two further, more general, reasons. First, it sheds new light on important aspects of French intellectual life in the fin de siècle, in particular regarding the insularity and self-sufficiency of the French intellectual space and the interplay between dominant and heterodox approaches to the conceptualization of the then emerging social sciences. One of the most perplexing features of the dominant historiographical image of Sorel is that it portrays him as a sui generis thinker, difficult to label, whose relation with the intellectual traditions surrounding him is either denied or investigated very selectivelymostly in terms of a poorly conceptualized Bergsonism. ${ }^{4}$ It is easy to see how this image cannot but portray only half of the truth.

3 Michel Charzat, "Avant-propos," in Cahiers de l'Herne-Georges Sorel, ed. Michel Charzat (Paris: Editions de l'Herne, 1986), 9.

4 See for example Mark Antliff, Avant-Garde Fascism: The Mobilization of Myth, Art, and Culture in France 1909-1939 (Durham, NC: Duke University Press, 2007), 4. For a more historically accu- 
It is, in fact, precisely his polemical mode of intellectual production, marked by constant critical engagement with those with whom he disagreed the most, which singles him out as the eccezionale normale of French intellectual life of the period: as the exception which can be used to understand the norm. As we shall see in this introduction, the "Study on Vico" emerges from a multiplicity of debates and networks of ideas in which Sorel was immersed and which guided him in the development of his own positions. Ranging from the French debate on the methodology of the social sciences to the Europe-wide reflection around the basic tenets of Marxian analysis, these various contexts of production of the "Study on Vico" not only help us understand the text, but, crucially, can in their turn be illuminated by it.

Second, Sorel's engagement with Vico presages in provocative ways major themes of interwar Marxist thought. Though Sorel lacks, partly for chronological reasons, a theory of alienation, his entire reflection on Marxism is based on an anti-deterministic historical ontology cast in terms of collective human agency. If we take seriously the Italian sources from which Sorel's interest in Vico originated - the remnants of a mid-19th century Italian Hegelian tradition and the philosophical forefathers of Antonio Gramsci-and if we look at how some of Vico's ideas shaped Sorel's understanding of Marxism as a theory of collective historical subjectivity, we may be brought to consider the possibility of an important pre-war precedent in the tradition of thought normally known as humanist Marxism. The present text will shed light on the above points by looking both to biographical elements and to the wider landscape of French and European intellectual life of the period.

Despite the fact that Sorel was an omnivorous reader and wrote, not always with equal insight, on an impressively large number of topics ranging from Biblical exegesis to physics, from philosophy to history, the "Study on Vico" is not merely the result of intellectual curiosity for the 18th century Italian philosopher. It emerges from a complex context that can be accounted for in terms of essentially three elements. First, it is linked to epistemological questions, questions to which Sorel had been dedicating energy for some time, and which found answers in some of Vico's ideas. Second is the particular situation of Marxism in France in the 189os, which both allowed and forced Sorel to attempt an operation of theoretical reinvention-what we here call "Sorelian revisionism." Third, a network of international contacts allowed Sorel to benefit from the decisive intermediation of Italian historicist Marxists. These

rate account, see François Azouvi, La gloire de Bergson. Essai sur le magistère philosophique (Paris: Gallimard, 2007). 
Italian historicists - Benedetto Croce and, more decisively, Antonio Labriolanot only led Sorel to the discovery of Michelet's translations of Vico, but also conditioned his understanding of the significance of Vichian ideas for Marxism. ${ }^{5}$

Much of the focus and the analytical depth of this introduction will be concentrated on these three immediate contexts of the "Study on Vico". Nonetheless, we also add a wider biographical sketch of Sorel. This is not only to show the centrality and significance of the work here translated to Sorel's wider trajectory, but also to present, albeit synthetically, a different portrait of a writer too often seen as a mere precursor of certain interwar intellectual and political tendencies.

The Early Years of Georges Sorel

It is easy, when dealing with Sorel, to reduce biography to bibliography, to see the man as mere thinker and to study him purely through the many writings and letters he left behind. And yet, when he published his first work in 1886, Sorel was already $38 .{ }^{6}$ At the time, he was living in Perpignan, working as an engineer for the French state. Six years later he would resign from his job and quit the Pyrenean city to move, with his partner Marie, to Boulogne-sur-Seine, near Paris, in order to become a full-time intellectual. He was 45 years of age.

He was born in 1847 in Cherbourg, into the middle class branch of a relatively important Normand Catholic family. ${ }^{7}$ His father was a small businessman and his mother the daughter of the mayor of the nearby town of Barfleur. Sorel's rising social trajectory, like that of his brothers, is linked with the French state and its educational institutions. A gifted student, Georges studied at the local

5 As Sorel reveals in the "Study on Vico," he was reading Vico's works in the French translation by Michelet, whose complete works were published between 1893 and 1898 by Flammarion. The volume on Vico-number 27 in the 40-volume collection—included "in addition to the New Science, Vico's autobiography, the treatise on the ancient wisdom of Italy and some minor works." See Jules Michelet, Oeuvres complétes: Vico, ed. Gabriel Monod, vol. 27, 40 vols. (Paris: Flammarion, 1894).

6 Georges Sorel, "Sur les applications de la psychophysique," Revue philosophique de la France et de l'étranger 22 (October 1886): 363-375.

7 The historian and future president of the French Senate Albert Sorel, Georges' cousin, came from a wealthier branch of the family. As for the religious upbringing, though Georges eventually lost his faith, as late as 1872 he still spoke as a member of the Roman Church, as can be evinced by his letter to the bishop of Orléans, Monseigneur Félix Dupanloup. See Patrice Rolland, “Georges Sorel, la science et la religion," Mil neuf cent 22 (2004): 207-215. 
Collège de Cherbourg, where he won a number of prizes in mathematics, and where he earned a double qualification, both scientific (baccalauréat ès sciences) and humanistic (baccaluréat ès lettres). Some time after the completion of Georges' schooling, the family moved from Cherbourg to Paris. Apparently, this move was decided in order to secure more business opportunities in the capital. Nonetheless, it is reasonable to suppose that it was a different kind of investment in the family's future that the parents were after: moving to Paris meant allowing the three children Georges, Anatole, and Ernest to pursue their education in some of the country's most important schools.

In 1864, Georges is at the Collège Imperial Rollin, taking preparatory classes for the entrance exam at the École Polytechnique, which he will successfully pass in the following year, on his first attempt. ${ }^{8}$ With the exception of some mediocre grades in French literature and German, his education at the École was a success: ranked 1oth out of 133 pupils at the end of the two years, he could, in virtue of this positioning, choose a specialization of his liking, and ended up entering the École des Ponts et Chaussées, where he completed his studies in 1870 . Upon graduation, he entered his post as a military engineer for the French state. His first working year-a decisive one in French history - was spent in the newly acquired Corsica. When he returned to the French mainland in July 1871 everything had changed: France had lost the war with Prussia, the empire of Napoleon III had collapsed, a republic had been proclaimed, and a short-lived Parisian commune had been repressed with large amounts of bloodshed. Though he would come back to some of these events-especially the Commune-in his later writings, there are no records of how he experienced them as they were occurring.

He spent most of the 1870 s in southern France, first near Toulouse (Albi), and then closer to the Italian border (Draguignan, Gap). In 1876 he embarked for Mostaganem, 100 kilometres north of Oran, in colonial Algeria. In 1879 he moved to Perpignan, in the Pyrenees region, where he would spend the next 13 years, the last ones of his life as an engineer of the Ponts et Chaussées, and where he would begin writing and publishing. ${ }^{9}$

This first half of Sorel's life is shrouded in relative obscurity, especially when compared to the amount of sources and works which pertain to the second half, which he spent as an increasingly public intellectual. ${ }^{10}$ Nonethe-

$8 \quad$ Also Ernest and Anatole will end up in the École Polytechnique.

9 Most of this biographical sketch is derived from Pierre Andreu, Notre maître, M. Sorel (Paris: Marcel Rivière, 1953).

10 A notable exception is Alice Ingold, "Penser à l'épreuve des conflits. Georges Sorel ingénieur hydraulique à Perpignan," Mil neuf cent 32 (2014): 11-52. 
less, a few elements of his intellectual and political formation can be deduced and must be highlighted. It is clear that both his education-at the École Polytechnique first and then at the Ponts et Chausées - and his 23 years of work as an engineer were important in determining the preferences and sensitivities that Sorel matured over the years and which informed his written work.

And yet, they are often misunderstood. In his Road to Serfdom, for example, Hayek locates Sorel in a technocratic, anti-liberal, and hyper-rationalistic tradition of thought that, because it aspires to rule through science, is at the root of totalitarian regimes. ${ }^{11}$ It seems tempting to accept such a narrative, especially if we think of the great French dirigiste tradition, which, starting with positivism, was embodied in institutions like the École Polytechnique - an institution which Hayek described as the "source of the scientistic hubris," claiming that it was the locus of elaboration of "the most fantastic plans for the reorganization of society," continuously spawning social reformers throughout the 19th century, all the way "down to Georges Sorel."12 The greatest state-coordinated plan of economic development of the French 19th century, the plan Freycinet, after all originated from a former polytechnicien, the then minister of public works Charles de Freycinet.

And yet, the historical record is less straightforward. To start with, we should recognize that Hayek's strict dichotomy between liberalism and technocracy is polemical and strategic more than historical. The history of the Saint-Simonian movement as well as the economic policies of the Second Empire show their compatibility. It was, after all, Michel Chevalier, a former polytechnicien and a Saint-Simonian, who managed to secure the anti-protectionist commercial treaty with England in 186o. Moreover, even accepting the centrality of the École Polytechnique and the École des Ponts et Chausées to a French tradition of technocratic governance, one must be reminded that institutions are not to be conceptualised as isolated monoliths, impervious to outside influences and

11 Friedrich Hayek, The Road to Serfdom [1944] (Abingdon: Routledge, 2001), 161.

12 Friedrich Hayek, The Counter-Revolution of Science. Studies on the Abuse of Reason (Glencoe, IL: The Free Press, 1955), 113. Isaiah Berlin casts Sorel in a similar mould, although as in revolt, finally, against the smooth, scientifically administered world. For a different and more historical approach to the Saint-Simonians more generally, see Robert Carlisle, The Proffered Crown. Saint-Simonianism and the Doctrine of Hope (Baltimore: John Hopkins, 1987); more recently, and dealing in particular with Algeria, Osama Abi-Mershed, Apostles of Modernity. Saint Simonians and the Civilizing Mission in Algeria (Standord: Stanford University Press, 2010). Theodore Porter offers a broad critique of a simplistic technocratic framing in his Trust in numbers. The Pursuit of Objectivity in Science and Public Life (Princeton, NJ: Princeton University Press, 1995), especially in chapter 6. 
internally uniform: if we look at Sorel's teacher of political economy at the Ponts et Chaussées, we find, for example, a leading French liberal economist, Joseph Garnier. ${ }^{13}$ Most importantly, however, one cannot assume that an individual is always the unmediated product of the institutions in which he develops. Certainly, Sorel was not.

In fact, a convincing case can be made that one of Sorel's deepest and most persisting political inclinations - an often undetected political liberalismwas based on a rejection of the sort of technocracy which he encountered during his education in these institutions. ${ }^{14}$ The constant attacks on Auguste Comte and the positivists, defined in the Reflections on Violence as the representatives of "mediocrity, pride and pedantry," are only one small piece of evidence for this. ${ }^{15}$ Or should one recall the critique, again articulated in the Reflections, of utopias, whose main problem is precisely that of being "an intellectual product" and merely "the work of theorists" ?16 There are countless examples of Sorel's fierce objections to various forms of technocratic rule by experts, which he associated with political centralism and individual oppression, and to which he objected on epistemological as well as political grounds.

In the 1889 Procès de Socrate, written while still in Perpignan, Sorel outlines a connection between a monistic and excessively rationalistic way of thinking about science and certain forms of political community: to a Socratic conception of rationality, in other words, corresponds a Socratic conception of politics. Drawing parallels between early protestants, Jesuit missionaries, and the French revolutionaries of ${ }_{1793}$, Sorel argues that what unites these diverse historical examples is their "ecclesiastical" conception of the state, in which "the citizen can only aspire to one type of liberty, the liberty of the good."17 A few pages later, Sorel explicitly connects this ecclesiastical conception of the state to Jules Ferry's laws on public education, which in 1881 and 1882 had instituted a free, compulsory, and secular education system in France. Sorel's reflections on these laws is deeply pessimistic, and the only glimmer of hope rests, for him, on the inefficiencies of democratic institutions. But if the project of national

13 See the Annuaire du ministére de l'agriculture, du commerce et des travaux publics pour l'année 1867, 135 and Annuaire du ministére de l'agriculture, du commerce et des travaux publics pour l'année 1868, 185. Both list Garnier as full professor. Archive de l'École des Ponts et Chaussées, cotes 1972.

14 For a generally convincing case for Sorel as a conservative liberal, see Marco Gervasoni, Georges Sorel: Una biografia intellettuale (Milano: Unicopli, 1997).

15 Georges Sorel, Reflections on Violence [1908], ed. Jeremy Jennings (Cambridge: Cambridge University Press, 1999), 134.

16 Ibid., 28.

17 Georges Sorel, Le procès de Socrate (Paris: Alcan, 1889), 7 . 
education were to be successful, "France would become a branch of the old missions in Paraguay, a truly Socratic state."18

Examples of this kind could be multiplied, from his reading of the Bolsheviks and Lenin as federalists, to the constant hostility to the French revolutionary tradition, read through the anti-centralist lenses of Tocqueville. ${ }^{19}$ The importance of federalism and anti-statism to Sorel's political identity are, indeed, in stark contrast to his education and upbringing and, it is worth underlining, are often underpinned by a pluralist epistemology. Without being excessively biographical, these political and intellectual inclinations could be interpreted as a rejection of the heritage of institutions such as the École Polytechnique and the École des Ponts et Chausées, as well as of the Republican state which he served until 1892. The very early retirement, at the age of 45 , suggests a degree of uneasiness vis à vis the institutions in which he spent the first part of his life-yet his desire to retain the customarily awarded légion d'honneur, which he wore even into anarchist bookshops, gives evidence of a certain kind of pride in his work.

The most important legacy inherited by Sorel from his first 40 years of life was his interest in questions of epistemology and philosophy of science. With the exception of some historical works, the first years of Sorel's production are dominated by interventions in debates regarding experimental psychology, epistemology, the status of mathematical propositions, and so on. As we shall explain better in the following paragraphs, this conceptual terrain, this interrogation on the epistemic status of scientific assertions, is a key feature of European intellectual life in the fin de siècle. It is mostly from this angle that Sorel read Vico, in an attempt to articulate a Marxist approach to social science both in terms of practice and in terms of method. This aspect of Sorel's production, i.e. the reflection upon the epistemology and methodology of social and natural science, is of crucial importance, not only because it is a decisive context to understanding the "Study on Vico," but also because it is one of Sorel's most constant theoretical concerns, from his writings of the 188 os to the last book he published, the 1921 Utilité du Pragmatisme. And yet, it is an aspect which is regularly underplayed and obfuscated in the dominant historiographical treatments of Sorel.

\footnotetext{
18 Ibid., 9.

19 Letter to Agostino Lanzillo, 8/10/1918 Cher camarade ... Georges Sorel ad Agostino Lanzillo 1909-1921, ed. Franco Germinario (Brescia: Fondazione Micheletti, 1994), 248.
} 
Take for example Zeev Sternhell's Birth of Fascist Ideology, whose famous opening chapter contains what is probably the most influential portrait of Georges Sorel in the last half century. Sternhell's portrait is dominated by a specific interpretation of some passages in the Reflections on Violence, which amount to the "theory that heroic myths and violence were creative of morality and virtue." ${ }^{20}$ This supposed connection between violence, myth, and morality is the basis of his interpretation of virtually the entirety of Sorel's work, which constitutes, in Sternhell's narrative, the decisive point of contact between Marxism and what will become fascism. Deviations from this idée fixe are treated, with some help from autobiographical snippets, as unimportant, and Sorel's complex intellectual trajectory is rendered as something which "despite appearances ... was perfectly coherent and followed a strict political logic."21

Even accepting the importance of this conceptual triad of myth, morality, and violence as a conceptual trinity, giving it so central a role in a reconstruction of Sorel's intellectual activity engenders a blindness to context, nuance, and complexity. It results, moreover, in a flat misreading or occlusion of substantial elements of Sorel's intellectual and political life. This is particularly evident if we look to the connection between social science and Marxism in Sorel's work. Though this connection emerges very evidently from the sources, Sternhell's view of Sorel as essentially a moralist forces him to gloss over it and to obscure it. Thus, we read that "Sorel took up Marxism with such enthusiasm and stuck to it so faithfully ... because he perceived in it a moral content." The abundant epistemological and scientific language of Sorel's Marxist works is portrayed as accidental, as the exuberance of a new convert to "scientific" socialism. ${ }^{22}$

However, the opposite of this view is true. It was the concern for the epistemology of the sciences, both natural and social, which led Sorel to Marxism, and not the "scientific" ambitions of Marxism which forced him to engage on the otherwise uninteresting terrain of epistemology. Most of Sorel's early Marxist texts, though peppered with references to Marx, constitute in fact the continuation of an epistemological reflection which he had begun some time before encountering the German thinker. Marx and Vico, in other words, were of interest to Sorel chiefly—though not exclusively—because they constituted

20 Sternhell, Asheri, and Sznajder, The Birth of Fascist Ideology. From Cultural Rebellion to Political Revolution (Princeton: Princeton University Press, 1994), 37.

21 Ibid.

22 Ibid., 40. It should be added that la morale was a key object of enquiry for late 19th century French social thinkers, and that therefore it is profoundly mistaken to pit it in such an antithetical manner to science. 
possible answers to some conceptual difficulties of a reflection on the limits and methods of both natural and social science, which he had been developing since the late 188 os. $^{23}$

The interest in Marxism, thus, was not dictated by a "moral content" which Sorel perceived in it, but instead by a problem "of philosophical order," as he himself wrote in an 1893 letter to the Revue philosophique in which he publicly announced his embracement of Marxism. ${ }^{24}$ The place in which this public statement is made is significant: not a political publication, but an academic and scientific one. The marginality of moral and political argumentations in what is Sorel's first public defence of Marxism is striking, and it is noteworthy that this defence takes place predominantly on the terrain of scientific enquiry. To be for or against Marx's ideas, writes Sorel, is "purely a question of doctrine," and more precisely it boils down to whether "exchange contains an element capable of being incorporated in a rational science, as K. Marx holds, or is it a phenomenon escaping all possible scientific categories, as Aristotle seems to think."25 The predominance of scientific and epistemological concerns over political and moral ones is self-evident, and it reveals the fact that Sorel's first years as a Marxist were mostly dedicated to the construction of a convincing Marxist position in the French debate on natural and social science. As he wrote in his first letter to Benedetto Croce, the task was to show that "socialism is worthy of belonging to the modern scientific movement."26

This emphasis on science - and in particular on the possibility of a science of economics-is typical of a period marked, in France as elsewhere, by the centrality of epistemological debates of this kind, on the legitimacy, methodology, and scope of scientific claims. Though often dismissed as a moment of "crisis" or even "destruction" of rationality, the so called belle époque was also a period of intellectual effervescence in which established philosophical understandings of scientific rationality in terms of laws, prediction, and determinism were subjected to critique and contestation. ${ }^{27}$ It was through participation in

23 See for example Georges Sorel, "Le calcul des probabilités et l'experiénce," Revue philosophique de la France et de l'étranger, XXIII (January 1887): 50-66; Georges Sorel, "De la cause en physique," Revue philosophique de la France et de l'étranger, Xxvi (November 1888): 464-48o.

24 Georges Sorel, "Science et socialisme," Revue philosophique de la France et de l'étranger $\operatorname{XxXV}($ May 1893): 511 .

25 Ibid., 509, 511.

26 Letter to Benedetto Croce, 20/12/1895, in Georges Sorel, "Lettere Di Georges Sorel a Benedetto Croce," La Critica 25 (1927): 38 .

27 For standards accounts of the period in terms of irrationalism see John Burrow, The Crisis of Reason. European Thought 1848-1914 (New Haven, Ст: Yale University Press, 2000) 
these kinds of debates that Sorel began to enter the main streams of French intellectual life, and this is not at all surprising if we remember that he was a gifted mathematician and an engineer by training and profession. His central theoretical project in the period between the late 1880s until 1894 was the development of an overarching epistemological scheme capable at the same time of vindicating the validity of scientific claims to truth and of opening up a space for the possibility of creative human agency. It is necessary to briefly dwell on this early Sorelian epistemology for it furnished to Sorel the conceptual problems to which Marx and Vico will represent answers.

Far from being an assault on reason, Sorel's early epistemological writings are riven by a large contradiction reflecting rather well some of the hesitations of the period: they search for a philosophy of science capable of representing more accurately the complexities of actual scientific practice, and, simultaneously, are concerned with the risk of relativizing or undermining scientific knowledge. Thus, on the one hand these texts outline an activist epistemology in which the importance to science of man-made conceptual instruments-something which Sorel first calls schemas and subsequently expressive supports - is repeatedly underlined and which draws him towards a proto-sociology of science and towards an awareness of the historicity of scientific claims to truth. On the other hand, however, they insist on the ability of science to make claims about the world, rejecting epistemological conventionalism - "the old mistake of universal consensus" - and holding on to a view of "rational science" based on scientific realism, determinism, and causal necessities. ${ }^{28}$

The resulting epistemology-formulated most comprehensively in the 1894 essay L'ancienne et la nouvelle métaphysique — was unsurprisingly dualistic. It

and Georg Lukacs, The Destruction of Reason [1954] (Atlantic Highlands, NJ: Humanities Press, 1981). For a more historically sensitive reconstruction see Eugenio Garin, "Note sul pensiero del novecento: 'Rinascita dell'idealismo', polemica antipositivistica e 'ragioni' dell'irrazionale," Rivista critica di storia della filosofia 33 (1978): 209-223; 308-325; 398-404.

Georges Sorel, D'Aristote à Marx [1894] (Paris: Marcel Rivière, 1935), 217. The text from which the citation comes is the "Ancienne et nouvelle métaphysique," which was originally published in three installments - between March and June 1894-in the Ére nouvelle. Citations in this introduction come from the 1935 integral re-publication of the text under the title D'Aristote à Marx. While in this period Sorel always maintains a conception of scientific explanation in terms of causal laws, he oscillates quite a bit on the issue of determinism. In some passages, he commits to scientific realism and postulates an ontological determinism of the natural world. In other passages, he seems to suggest a merely experimental determinism, constructed in highly specific experimental conditions and not necessarily reflecting the actual structure of the natural world. 
postulated a distinction between a milieu artificiel in which humans freely create "sequences whose ordering is our decision" and a milieu cosmique or milieu naturel governed by necessary relations of cause and effect. ${ }^{29}$ The experimental moment acted as the conjunction between these two realms of freedom and necessity: only in experimental practice could the freely created tools of humans interrogate nature and reveal the laws and causes which governed it.

While this scheme offered some conceptual plausibility when applied to the natural sciences - in particular distinguishing between two very different projects, predictive capacity and systematic or rational knowledge-serious problems emerged in the attempt to use it to study social phenomena. ${ }^{30}$ The very idea of a science of society could not but show the limits of this early Sorelian dualism: if the social world, the milieu artificiel, is conceptualized as marked most profoundly by the fact of creative agency, then it follows that explaining it in strictly speaking scientific terms-i.e. in terms of laws and necessities-is very difficult, if not an outright conceptual impossibility. As soon as Sorel began to reflect seriously on the epistemology of the social sciences, this difficulty emerged.

Thus, for example, in an 1892 study of Proudhon concerned in part with the question of the science of economics, Sorel, after having characterized labour as a specifically human type of creative agency, proceeded to suggest that a science of economics is only plausible once this creative aspect has been removed from the picture. This can be done through taking production holistically, not from the perspective of the individual producer but from that of social production: "products, seen from the perspective of the social being, are capable of being measured." ${ }^{31} \mathrm{~A}$ few years later Sorel couched the same argument in Marxist references, arguing that the only possibility for social science was the removal of the creative aspect and the isolation of supposed deterministic relation between variables:

29 Ibid., 264.

30 If Sorel's solutions to the problem of objectivity in the social sciences were in some respects idiosyncratic, they were less so than might at first appear to be the case, and certainly the problem he confronted was a widely shared one in European intellectual life of the period between the late 1880s and the early 1920s. Sorel's difficulties and hesitations should be inserted into a wider problematic encompassing Durkheim, Dilthey, and Max Weber. The classic and still useful formulation of this is Henry Stuart Hughes, Consciousness and Society (New York: Vintage Books, 1958).

31 Georges Sorel, "Essai sur la philosophie de Proudhon," Revue philosophique de la France et de l'étranger 33-34 (June-July 1892): 628. 
... one does not try to establish under what influences the contracting parties operate, what are the representations directing the development of their thoughts; in a word, all the psychological apparatus disappears. We take a relation, that of capital and usury, excluding every individual phenomenon and we ask what this relation is, rationally. To answer this question, we do not need to take into account people, with their passions and incidents; we only have to imagine a machine-like support [un support machinal] capable of producing the original effect that we are examining. ${ }^{32}$

But though this anti-individualistic, quasi-structuralist, and anti-psychological direction was the one which Sorel tried to pursue in the early 189os, strong tendencies going in the opposite direction kept surfacing in his writings, tendencies which insisted not so much on methodological individualism as on the importance of creative agency and collective psychology, and which greatly complicated the attempt to offer causal explanations. ${ }^{33}$

This indecision surfaced very evidently in Sorel's involvement in the important debate on the methodological bases of sociology which was occurring at the time between Gabriel Tarde and Émile Durkheim. In this debate between Tarde's theory of imitation - which explained social behaviour in terms of imitative interaction amongst individuals - and Durkheim's notion of social fact - which contended that the object of sociology was precisely that which could not be explained in terms of individual behaviour-Sorel sided forcefully with the latter's methodological holism. This is coherent with Sorel's longstanding opposition to epistemological individualism, and we should not be surprised to see him accusing Tarde of "anti-scientific tendencies." ${ }^{34}$

And yet, when Durkheim's 1894 articles in the Revue philosophique were published a year later, as the Régles de la méthode sociologique, Sorel's long review expressed only a very qualified approval and formulated an extremely interesting series of objections. ${ }^{35}$ To start with, Sorel remarked that sociology cannot

32 Sorel, D'Aristote à Marx, 233.

33 In the above-cited essay on Proudhon, for example, Sorel defines human labour as purposive action, concluding that “... work, from the perspective of economics, is a moral phenomenon, and thus incapable of being included in any equation containing material quantities". Sorel, "Essai sur la philosophie de Proudhon," 627.

34 Georges Sorel, "Les théories penales de мм. Durkheim et Tarde," Archivio di psichiatria, scienze penali, ed antropologia criminale 16 (1895): 221.

35 In his biography of Durkheim, Marcel Fournier claims that "The Durkheim who interested Sorel was, for political reasons, not so much the author of the Rules as that of The Division of Labour in Society" Marcel Fournier, Émile Durkheim. A Biography, trans. David Macey 
be an experimental science, but has to limit itself to observation. Secondly, the objects which it observes are statistically constructed types, what Sorel called "type moyen" or "état moyen."36 Moreover, Sorel was left uneasy by Durkheim's unwillingness to either affirm or deny social determinism. This was problematic to him, because he still held to the view that a legitimately scientific explanation depends on the presence of determinism: "Physics and chemistry do not imply a loosening of the deterministic chain: their laws either hold or do not hold and apply to each individual [case]. But how can we talk of causes (similar to those of physics) in sociology where the elements connected are fictions devoid of individual reality?"37 Sorel's conclusion was that Durkheimian sociology could not aspire to become a real social science, precisely because it could not establish sufficiently strong causal connections and thus produce explanations in terms of law.

Against these shortcomings of Durkheimian sociology, Sorel offered two alternative and mutually exclusive ideals of social science. On the one hand, there was the kind of Marxist answer we have seen above. If Durkheimian sociology were capable of examining what Marx shows to be the essence of the social world, i.e. the "system of production and exchange," then it could become scientific, because economics is a sphere in which determinism holds and can be thus explained in terms of laws. ${ }^{38}$ On the other hand, however, Sorel underlined the inability of sociology to understand historical transformation, and pitted against Durkheim a very different Marxism, based not on the laws of economics but on class struggle. Thanks to this doctrine, for Sorel, "we can follow the real historical process, whereas the one described by our author [Durkheim] is merely schematic and logical. Thanks to the theory of classes, socialists do not connect ends to imaginary entities ... but to real humans collected in groups." 39

The theory of class struggle, in other words, creates a conceptual space for human agency. It allows the social scientist to penetrate into "what is striking in the human milieu, that is to say action considered from the perspective

(Cambridge: Cambridge University Press, 2013), 185. While it is true that Sorel did identify immediately Durkheim as what we may call a theorist of the Republic, the opposite is true. In this period more of an epistemologist than a political activist, Sorel was much more interested in Durkheim's methodological assertions than in his analysis of organic and mechanic solidarity: the vast majority of Sorel's review engages with Durkheim's Régles on the level of the methodology of the social sciences.

36 Georges Sorel, "Les théories de M. Durkheim," Le Devenir social 1 (1895): 4.

37 Ibid., 7 .

38 Ibid., 161.

39 Ibid., 24. 
of the agent." 40 According to Sorel this gives us a way of "recognising what is truly human in sociology; we can correctly define the active groups ... their movements must be described through psychological qualifications and every analogy drawn from physics can only lead us to errors."41 This new role for psychology — which when "put in its proper place" can "equip sociology with explanations" - should be underlined because it is pitted against the kind of explanations offered by the natural sciences, i.e. causal ones. ${ }^{42}$ The point is not merely that Sorel here, rather than looking for pockets of determinism in the social world, chose to focus precisely on what is by definition non-determined, human agency. It is also that this choice of focus implies a completely different account of what a social scientific explanation is, making explanations in terms of laws inappropriate. To a different kind of social scientific explanation must, accordingly, correspond a different ontology of the social, based not on deterministic causal relations but on agency:

If we were to operate like M. Durkheim and adopt a terminology borrowed from physics, we would need, after having recognised the relevant [social] groups, their tendencies, the general features of their movements, to determine their mass, their density, and their tension. There is a much better way of proceeding. Institutions do not have a mysterious origin: they are human works. 'Social relations' says Marx 'are as much produced by men as linen, flax, etc' 43

The review of Durkheim's Régles was published in April 1895, a year and a half before the publication of the "Study on Vico." But the conceptual question to which Vico provided the answer, as we can see, had already been formulated. Torn between an understanding of the social world as constituted most essentially by human creative agency and a conception of science based on determinism, Sorel's epistemology had reached a point of crisis. The choice to adopt an ontology of the social based on agency, making of collectivities and their creative capacity the heart of the social world and of their conflicts the engine of historical transformation, meant that any conception of social science based on law and causal relations was to be abandoned. But then in what way could a study of society be scientific?

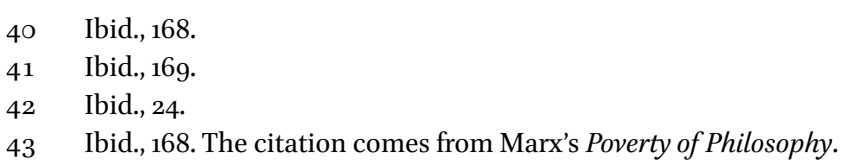


For this, a different epistemological criterion was needed, and in Vico's verum ipsum factum Sorel found precisely what he was looking for: it furnished Sorel with a type of knowledge which could allow him to deal with a social world whose essence was creative agency. Hence the repeated insistence, in the "Study on Vico," on the connection between the human creation of history and the fact that this is what allows us to understand it. The idea that knowledge consists not in the representation of a reality independent from the scientific observer but instead in the understanding of the productions of a creative subject's activity, allowed Sorel to resolve, in this historicist and subjectivist direction, his epistemological indecisions. ${ }^{44}$ The objects of social scientific knowledge were not deterministic causal relations but, instead, the ways in which humans create ideas, institutions, cultures, classes, and so on. Thanks to what Sorel called Vico's "ideogenetic" law, we have a way of connecting any historical object to its creative subject, be this subject a class, an individual, or whatever else. This process always remains fully immanent, rooted in historicity and human agency: "In passing from empiricism to reasoned understanding, from practice to science" writes Sorel in the text "we move only within an historical order founded on human ideas," before adding that "understood in this way, the New Science is a history of human ideas."

To be sure, Sorel is deeply, and at times painfully, aware of the relativistic implications of this full commitment to historicity. Once this Vichian stance is accepted, it means that everything has to be conceived as an historically situated human production: science, ethics, and law hence become dangerously pluralistic. This awareness surfaces most clearly in Sorel's rejection of Vico's transcendental solution to this problem of relativism, i.e. the notion of a cyclical history.

Thus ideal history has perished ... However, the ethical problem for which it was thought to be such a [809] simple and satisfying solution remains ... Critique of the idea of divinity has shaken the foundations of all knowledge that drew its certitude from the ancient idea of "God in nature." Science no longer seems, today, safe from contingency ... Nothing is served by denying the difficulties that result from these new principles, but this is not a reason to revive famously incorrect doctrines. The notion of ideal

44 For philosophical clarifications on this understanding of knowledge see the still useful Isaiah Berlin, "Vico's Concept of Knowledge," in Against the Current. Essays in the History of Ideas, ed. Henry Hardy, 2nd ed. (Princeton, NJ: Princeton University Press, 2013), 140-150; Benedetto Croce, La filosofia di Giambattista Vico (Bari: Laterza, 1922). 
history was quite useful, but it is false. We will not return to it to give an illusory solution to an ethical problem that is so serious and immediate.

This abandonment of a transcendent objectivity in favour of an immanent plurality is typical of large strands of 19th century philosophy: one finds it in various Hegelianisms, in different forms of pragmatism, in Nietzsche, as well as, of course, in Karl Marx. ${ }^{45}$ This is why it is incorrect to interpret, as some commentators have, Sorel's insistence on the human "creation" of history as a form of technological determinism. ${ }^{46}$ Though Sorel does indeed insist on the material and practical origin of human ideas, this material origin is still marked by the essential openness of human agency. It is more correct to speak, as Jeremy Jennings does, of the effect of Vico's verum ipsum factum in terms of "a fundamental revision of our conception of the ties that connected science to reality," even if strictly speaking the Vichian principle ultimately demands an abolition of this dualism of science and reality. ${ }^{47}$

\section{French Marxism in the 189 os}

This historical theory of knowledge not only chimed with some of Sorel's earlier epistemological intuitions, but fully transformed his understanding of science. It is not a coincidence that in the years following its discovery Sorel should be busy with a deep theoretical reconfiguration of Marxism along these historicist lines, abandoning the notion of Marxism as an ahistorical scheme of social development and increasingly seeing the doctrine as a form of proletarian selfconsciousness. This theoretical reconfiguration - which furnished the basis of Sorelian syndicalism in the new century—is what we call in this introduction "Sorelian revisionism."

But if there were, as we have shown, important theoretical reasons for this epistemological break in Sorel's thought, we should not underestimate the more concrete intellectual circumstances in which Sorel operated. As we have said, Sorel approached Vico as a social theorist attempting to articulate a Marx-

\footnotetext{
45 See Leszek Kolakowski, "Karl Marx and the classical definition of truth," in The Two Eyes of Spinoza and Other Essays on Philosophers (South Bends, IN: St. Augustine's Press, 2004), 173-195.

46 Anne-Sophie Menasseyre, “Sorel Lecteur de Vico," in Georges Sorel, Étude sur Vico et autres textes, ed. Anne-Sophie Menasseyre (Paris: Champion, 2007), 7-73.

47 Jeremy Jennings, "Sorel, Vico, and Marx," in Vico and Marx. Affinities and Contrasts, ed. Giorgio Tagliacozzo (Atlantic Highlands, NJ: Humanities Press, 1983), 331.
} 
ist position in the field of the social sciences. This positioning implied precise constraints and opportunities, and we can say that the operation of theoretical redescription of Marxism which Sorel began with the "Study on Vico" can be accounted for also in terms of the marginality of Marxism in the France of the fin de siècle.

This political and intellectual marginality had political and ideological explanations. Whereas in Germany there was the SPD-a large, organized, powerful mass party ideologically committed to Marxism-in France the socialist front was smaller, more fragmented, and often engaged in factional infighting. ${ }^{48}$ To this political fragmentation corresponded an ideological fragmentation. Whereas the German workers' movement could, mostly thanks to the ability of the SPD to finance publishing houses and publications, rely on a single codified Marxist doctrine, in France ideological competition abounded. Pre-existing national traditions of socialist reflection, positivism, anarchism, and above all French republicanism all contended with Marxism for the allegiance of the working class and the progressive bourgeois intellectuals.

The main space of implantation of Marxism in France was the only Marxist party in the hexagon, Jules Guesde's Parti Ouvrier, tellingly renamed Parti Ouvrier Français (POF) in the preparation for the 1893 general election. Crucially, one of the key features of the POF was its relative neglect of the theoretical development of Marxism, an ideology which it understood predominantly in political and electoral terms. Michelle Perrot goes as far as speaking of the "complete absence of Guesdist contributions to research in all the fields of what we call human sciences." 49 The deeply political nature of Guesdist Marxism needs to be underlined: like most other Marxist parties in the period of the Second International, the Guesdists understood Marxism mostly as a language of political mobilization and as a rhetorical weapon directed not just against the bourgeoisie but also against competing socialist ideological options. ${ }^{50}$ Therefore, rather than theoretical poverty, we should speak of disinterest in the elab-

48 In a very summary overview of French socialism in the period, Claude Willard lists as many as five distinct tendencies: anarchists, Guesdists, Allemanists, Broussists, and Blanquists. See Claude Willard, Socialisme et communisme Français (Paris: Colin, 1978), 45-78.

49 Michelle Perrot, "Les guesdistes: controverses sur l' introduction du marxisme en France," Annales: Économies, sociétés, civilisations 22 (1967): 705.

50 Daniel Lindenberg, Le marxisme introuvable (Paris: U GE, 1979), 76-77. Robert Stuart makes a similar, though more forceful, argument, suggesting that the insistence on the theoretical inconsistence of Guesdism should be seen as an instance of "scholarly intellectualism" and that Marxism ought to be understood more as a language of class than as a contribution to social science. See Robert Stuart, Marxism at work. Ideology, class, and French socialism during the Third Republic (Cambridge: Cambridge University Press, 1992), 28. 
oration of a more theoretically sophisticated form of Marxism. Simply put, the party did political work and in the 189 os French intellectuals, especially academics, had hardly begun to embrace Marxism. ${ }^{51}$

This brief contextualisation allows us to understand better the possibilities which Sorel could exploit. Ideological competition made the struggle of ideas relevant, and the disinterest of Guesdists towards theory made this task even more urgent. Most importantly, however, the absence of a large party implied conditions of relative freedom for intellectuals interested in the development of Marxist theory. Though lacking the resources which a party like the SPD could offer to their German counterparts, French Marxists could deepen their understanding of theory free from the stringent demands of electoral propaganda.

Take, for example, the only two journals of Marxist theory in the France of the time, the short-lived Ére nouvelle and its successor Le Devenir social, publications in which Sorel was heavily involved. Clearly, as explicitly Marxist periodicals, they entertained friendly relations with the POF, as can be seen not only by the translations of many classic texts of European Marxism of the time-Engels, Marx, Plekhanov-but also by the regular contribution of key POF figures such as Gabriel Deville and Paul Lafargue. And yet, these were not party journals. Had they been so, the central role played by complete outsiders like Sorel and Diamandy would have been unthinkable. ${ }^{52}$ Furthermore, and most decisively, the terrain of engagement chosen by these publications was one which the POF had chosen largely to ignore: that of high culture. If we look, for example, at the strenuous activity of militant book reviewing of these publications we see the clear attempt to develop a Marxist point of view on the key French debates of the time: the polemical targets of both books reviews and longer essays are figures such as Durkheim, Tarde, Brunetière, Pierre Janet, and Gustave de Molinari.

These opportunities granted to Sorel the space to tackle Marxism in a creative and original manner. But we should also pay attention to the constraints which pushed Sorel towards his work of theoretical revision. As we have said,

51 See Christophe Prochasson, "Sur la reception du marxisme en France; le cas Andler (18901920)," Revue de synthèse 110, no. 1 (1989): 85-108. And for a more recent contextualization the second chapter especially of Julian Wright, Socialism and the Experience of Time (Oxford, 2017).

52 Georges Diamandy, founder of the Ére nouvelle, was at the time a student in Paris, recently arrived from Romania, and a member of the Étudiants Socialistes Révolutionnaires Internationalistes. The publication emerged thus from a radical student milieu and not from the POF. Diamandy certainly had relations with the POF, but he was not a party member. See Lindenberg, Le marxisme introuvable, $15^{2-153}$. 
although the details of Marx's work were relatively unknown in France, there still was a strong idea of what Marxism was. This was to a large extent based on Guesdism and took Marxism to mean a form of historical determinism that understood the social world on the basis of economics and had a conflictual view of society at its core.

Hence, according to the liberal Léon Say, the admirers of Karl Marx held that "his greatest discovery has been that of the historical law of revolution" which consisted in claiming that "history has always been marked by class struggles based on economic interests and that what happened in the past will reproduce itself in the future."53 These accusations of idolatry of conflict and historical and economic determinism, it should be remarked, were also directed at Marxism by fellow socialists: for example, according to Gustave Rouanet, director of the Revue socialiste elected to the chamber of deputies in 1893, the theory consisted in a "simplistic" materialism masked "under the guise of scientific rigour." ${ }^{54}$ More articulately, Rouanet gave the following account of Marxism:

Purely materialist, last evolution of the German historico-fatalistic school, which was a reaction to French 18th century philosophy, Marx's thought is essentially anti-French ... We do not believe that the fatalistic understanding of historical evolution which emerges from Marx's theories is entirely correct. We believe that Marx has not taken sufficiently into consideration some factors of [historical] evolution. This will not prevent us, however, from praising his brilliant penetration of contemporary economic facts ... ${ }^{55}$

The cultural nationalism-identifying Marxism as essentially a German theory and thus as "anti-French" - should not go unnoticed. The familiar picture of Marxism as a form of "historical fatalism" whose analysis of social development is exclusively and one-sidedly based on economics is corroborated by the suggestion of a certain German barbarism and a love for violence. In describing the Hegelian origins of Marxist dialectics, Rouanet offers a quasi-Darwinist picture in which "strong, victorious people are the missionaries of the 'Idea'" and in which "war is the great judge" of history. ${ }^{56}$ This nationalistic element is relevant because beyond the general charges of economic and historical determinism

53 Léon Say, Contre le socialisme (Paris: Calmann-Lévy, 1896), 40.

54 Gustave Rouanet, "Le matérialisme économique de Marx et le socialisme Français (1)," $L a$ revue socialiste 5 (1887): 58 o.

55 Ibid., 396.

56 Ibid., 399 . 
often rested more precise accusations concerning Marxism's inability to grasp aspects of historical development - such as le droit or la morale - which were seen to be specifically "French" or tied to the national culture.

This deterministic understanding of Marxism was shared not only by adversaries of Marxists on the right and on the left, but also, importantly, by many Marxists. To an extent, this was not a French specificity, but reflected a wider European tendency, ultimately determined by the German leadership of the movement. But in France, Marx's materialism was almost unfailingly interpreted in these deterministic terms. As Anne-Sophie Menasseyre points out, a significant context to Sorel's engagement with Vico was represented by the debate over "materialism" and "idealism" between Jean Jaurès and the Marxist Paul Lafargue. While it may be an exaggeration to refer to it as the "true polemical horizon" of Sorel's intervention, the debate is still important, for it illustrates how Sorel's polemical targets included many Marxists. For what should be underlined, more than Sorel's obvious rejection of Jauressian idealism, is the implicit critique of what Menasseyre calls Lafargue's "monist determinism." ${ }^{57}$ As early as 1884 Lafargue had been producing synthetic explanations of the basics of Marxist theory in the form of pamphlets entitled Le matérialisme économique de K. Marx, material meant for wide distribution in which Lafargue outlined a deterministic Marxism and mentioned Vico. ${ }^{58}$ Sorel could hardly have felt it wise to openly criticize Lafargue, an important figure in French Marxism, whose long essay on Campanella appeared in 1895 in the pages of the Devenir social. ${ }^{59}$ However, he was certainly aware of Lafargue's

57 Menasseyre, 33, 36. Menasseyre suggests that Sorel opposes to Lafargue's "monist determinism" a "pluralist determinism," which is an awkward expression. What Sorel is doing in the "Study on Vico" is, more radically, a breaking of the links between scientific explanation and determinism. This kind of operation is, in fact, described accurately in Menasseyre, 37.

$5^{8}$ The work was divided in three parts, dealing with methodology (i.e. idealism and materialism), natural history, and human history. Paul Lafargue, Le matérialisme économique de K. Marx. L'idéalisme et le matérialisme dans l'histoire (Paris: Henry Oriol, 1884); Paul Lafargue, Le matérialisme économique de K. Marx. Le milieu naturel: Théorie darwinienne (Paris: Henry Oriol, 1884); Paul Lafargue, Le matérialisme économique de K. Marx. Le milieu artificiel: Théorie de la lutte de classe (Paris: Henry Oriol, 1884). Though Vico is only mentioned once in these pamphlets, the Neapolitan was an interest of Lafargue. When in 1909 he expanded his theoretical work on Marxism, Lafargue included a much more thorough discussion of Vico. See Paul Lafargue, Le déterminisme économique de K. Marx. Recherches sur l'origine et l'évolution des idées de justice, du bien, de l'ame, et de dieu (Paris: Giard et Brière, 1909). Notice how in 1884 he spoke of "matérialisme économique" and in 1909 of "déterminisme économique." On Lafargue, see Leslie Derfler, Paul Lafargue and the Flowering of French Socialism 1882-19n1 (Cambridge, MA: Harvard University Press, 1998). 
determinism, especially since his 1884 pamphlets had been republished in the Ére nouvelle in the summer of $1893 .{ }^{60}$ Certainly, Lafargue, with his simplistic deployment of the categories of "artificial" and "natural" milieu, was a target for Sorel. ${ }^{61}$

We can see how the conditions of French intellectual life of the time shaped Sorel's project of "showing that socialism is worthy of belonging to the modern scientific movement." In order to be successful, this kind of demonstration required, to start with, the targeting of an audience which was neglected by the POF: the academic and intellectual one which was interested in questions of historical theory and social scientific methodology. But more importantly, it required a rather substantial theoretical redescription. The task in short was that of offering to a specifically French public a Marxism which did not profess historical determinism, which could offer convincing explanations of phenomena like morality and law without reducing them to epiphenomena.

This operation of theoretical redescription, it needs to be repeated, targeted not only non-Marxists, but also the ways in which Marxists themselves understood the theory. Sorel's use of Vico, in other words, was a self-conscious attack on prevalent French interpretations of Marxism, expressed not only in Lafargue's deterministic use of Vico, but also, for example, in Jules Guesde's presentation of the class struggle as the "great law" of social development which will disappear only with the advent of socialism. ${ }^{62}$ Sorel instead maintained, as Antonio Labriola had written in the Devenir social, that historical materialism implied a broader perspective than Albert Schäffle's famous "question of the belly."63

January 1896, he thanks Croce for his article on Campanella, but informs him that it cannot be published, since it clashes too obviously with Lafargue's own work on the Italian friar. He adds "I began suspecting, reading what M. Lafargue said about Church Fathers ... that his article was the work of an incompetent man; but I did not believe that he could be as incompetent as you establish in such an irrefutable manner." Sorel to Croce, 14/1/1896, Sorel, "Lettere di Georges Sorel a Benedetto Croce," 39.

6o Paul Lafargue, "Le matérialisme économique de K. Marx," L'ére nouvelle 1 (1893): 46-58; $125^{-13} 8 ; 240-25^{2}$.

61 It is also the case that Jules Michelet's edition of Vico had recently been re-issued as part of a larger collected works of the French historian. Although Sorel does not make much of this explicitly, Michelet was among those adopted by the Third Republic as legitimating figures to the point of banalization. See Camille Creyghton, 'Commemorating Jules Michelet, 1876, 1882, 1898: The Productivity of Banality', French History, 2019. doi.org/10.1093/fh/crzo22.

62 Jules Guesde, Quatre ans de lutte de class à la chambre: 1893-1898 (Paris: Jacques, 1901), 210-211.

63 Antonio Labriola, "En mémoire du Manifeste du parti communiste," Devenir social 1 (1895): 244 . 
When seen from this perspective, many aspects of the "Study on Vico" become clearer. To start with, Sorel dedicates large sections of the work to historical analyses of the origins of law and ethics. Take, for example, section VIII, in which Sorel accompanies Vico in an overview of the evolution of criminal law; or the conclusion of the study in which class struggle is described as one "for the conquest of rights," i.e. as a struggle for the imposition of new ethical and juridical principles on society; or again, section IV in which he sketches the method followed by Vico for an historical study of law and complements this material with citations from Engels. In all of these instances what Sorel is trying to do is to offer to his readers examples of a Marxist approach to the study of history and society which does not reduce everything to a narrowly understood economics and which is capable of offering nuanced materialistic accounts of complex phenomena such as law and ethics-a Marxism that would be materialist, rather than economistic. As highlighted above, all forms of transcendental explanation are ruled out, even when, as in the case of Vico's storia ideale, they would nicely solve the problem of justifying the normativity of juridical and ethical systems. The method Sorel attempts to follow is materialistic in the sense that it forces us to look for the "origins of our metaphysical constructions in the more or less empirical constructions of social life." 64

Sorel's attack on determinism cannot however be reduced to these illustrations of the capability of Marxian analysis to offer complex and subtle accounts of phenomena such as morality and law. There is, in the "Study on Vico," a more fundamental and theoretically rich line of attack against determinism, which ultimately derives from the shift to verum ipsum factum and towards a conceptualisation of social scientific explanation different from causal explanation. There is, to start with, an open denial of historical progress: "Historical movement is not one homogenous development. It is not even possible to say, as in physics, that causes have immediate effects. There is a great complexity of changes acting on one another, and one of the most considerable objects of sociology is the study of decelerations and accelerations."

But even more profoundly, it should be appreciated how Sorel introduces a very large degree of complexity into the simplistic scheme of economic base and ideological superstructure with which Marxism was at the time associated. Though material conditions are of course tied to intellectual production and to

64 Durkheim's 1912 The elementary forms of religious life is a useful point of comparison here, in its arguments for the social origins of temporality, categories, and conceptual thought more generally. 
pensée réfléchie, there is a crucial mediation-human agency. This process of transfiguration of material conditions into ideas is to be accounted for, according to Sorel, in terms of laws of psychology. However, these laws are far less straightforward than Vico supposed them to be, and though some of Vico's psychological types remain valid for Sorel, the order of their succession is to be completely abandoned:

Psychological evolutions are sequences with their own existence and autonomy, arising in any era, mixing in society in the most confused way. Rather than a homogenous bloc, we have an interlacing of evolutions, which cannot be brought under any general definition because at any given instant we find them at all moments in their development. But economic conditions, social relations, all the historical complexes act on these evolutions to favour certain developments.

The plurality of terms through which Sorel describes material conditions should be underlined: "economic conditions, social relations, all the historical complexes." Not only did Sorel refuse to reduce material condition to economic ones - think of the complexity introduced by what Sorel calls Vico's "second ideogenetic law," the familial origin of moral ideas-but he also offered no theory capable of hierarchically organizing the various elements which constitute a given "historical complex." The picture is very far away from the image of economic and historical determinism with which Marxism was associated at the time. Progress is far from automatic, and psychology and human agency are at the centre of the historical process. But the laws of psychology offer little general guidance on how to deal with this historical material. Finally, though material factors remain decisive, they comprise a vast variety of phenomena and elements, with Sorel offering no criterion capable of determining a general scheme according to which their relation ought to be construed. In other words, in the Sorelian scheme it is not possible to speak of economic determination, not even in the last instance. He offers an architecture of the social world in which there is no final instance at all.

From what has been said above, we can begin to see how Sorel's "Study on Vico" presages important themes for later Marxist theorists. Sorel's psychology is drawn from Théodule Ribot rather than Sigmund Freud, but the problems he confronts in integrating it with Marxism are surprisingly similar. The problem of totality that so vexed what can at least provisionally be called Western Marxism, and which shaped in a broad way the reading of Vico by Györgi Lukacs and Theodore Adorno, for instance, has already to some degree been put aside by Sorel. By dissolving Vico's totalizing ideal history, Sorel recognized the danger 
of hypostatizing the making and knowing subject in Vico, a danger that, as Martin Jay has argued, constantly dogged later 2oth century Marxists in the form of the all-knowing revolutionary party. ${ }^{65}$

If for Vico this making and therefore knowing subject was tripled-God, the nations, the scholar-for Sorel it was doubled - the scholar and the institution. It is legitimate to ask after the cost in terms of analytic capacity to Sorel's Marxism of this de-totalization, but it should be clear that the materialist approach to history he first sketched out in the "Study on Vico" covers much ground to which later Marxists would return, and without much of what Sorel at least would likely have regarded as their Hegelian metaphysical baggage. ${ }^{66}$

\section{$4 \quad$ Italian Connections}

The "Study on Vico" represents Sorel's first substantial attempt at revision of Marxism. As we have shown, this revision results in part from long standing conceptual difficulties in Sorel's epistemological thought and in part from the desire to articulate a Marxism capable of overcoming common and at least sometimes legitimate objections of economic and historical determinism against it. It is in this work that we find the embryonic versions of ideas which Sorel will articulate with greater length and precision in the following years, and which will constitute the core of his revision of Marxism. The importance of the Vichian principle of verum ipsum factum to Sorel's historicist turn is evident. However, there is a crucial mediation between Sorel and Vico.

Both Sorel's reading of Vico and his subsequent revision of Marxism have to be made sense of in terms of the protracted relation which Sorel entertained with two Italian historicist thinkers, Benedetto Croce and Antonio Labriola.

65 Broadly, see Martin Jay, Marxism \& Totality. The Adventures of a Concept from Lukács to Habermas (Berkeley: University of California Press, 1984); for a tighter focus on Vico, see his "Vico and Western Marxism" [1978] reprinted in Martin Jay, Fin de siècle Socialism and Other Essays (London: Routledge, 1988).

66 Whether Sorel is still to be considered a Marxist at all having apparently given up on the explanatory power of the totalizing logic of capitalism, or if he would be better assigned to the somewhat controversial category of post-Marxist, is not a question the present historical introduction can adjudicate. The most rigorous critical work on Sorel from a Marxist rather than a historical point of view is Patrick Gaud, De la valeur-travail à la guerre en Europe (Paris: Harmattan, 2010). Perhaps the most exciting recent attempt to enroll Sorel in a revolutionary, as opposed to a Marxist, tradition alongside Frantz Fanon and Enrique Dussel is George Ciccariello-Maher, Decolonizing Dialectics (Durham, NC: Duke, 2017). 
Though Croce remained Sorel's lifelong correspondent, while Labriola not only died in 1904, but also fell out with Sorel before dying, it is in fact the latter whose influence is here more decisive.

First contact with the two Italians was established by Sorel when he was collaborating with the Devenir social, a publication which—-much like the Ére nouvelle - was marked by a very international authorship, also in part due to the limitations of the French Marxism of the time. It was likely Sorel who contacted Labriola, commissioning a piece for the Devenir in $1895 .{ }^{67}$ Labriola then wrote to Croce, encouraging him to both subscribe and contribute to the publication. ${ }^{68}$ Eventually, in December 1895 , Sorel wrote to Croce and, after having reassured him that this letter came with the approval of Labriola, specified some of the more general editorial guidelines for a possible contribution. ${ }^{69}$ Over the course of the following years, the three thinkers were deeply involved with each other and with a common project of theoretical clarification of Marxism, dictated, on both side of the Alps, by a common dissatisfaction with the dominant understandings of Marx's theory in the two countries.

Labriola appears particularly important for two reasons: first because he had long tried to blend the ideas of Vico and Marx, and second because of his profound influence on Sorel's attempt at theoretical revision of Marxism. A militant socialist and a university professor, already since the late $188 \mathrm{os}$ Labriola had been lecturing in the University of Rome on Marxism and historical materialism. Arguably the last member of the mid-19th century generation of Neapolitan Hegelians, Labriola's engagement with Marxism had been always marked by his desire to distinguish it from various forms of positivism

67 Labriola, "En mémoire du Manifeste du parti communiste." On Labriola and this text, see Roberto Dainotto, "Historical materialism as new humanism: Antonio Labriola's 'In memoria del Manifesto dei comunisti', Annali d'Italianistica 26 (2008): 265-282. For a perceptive treatment of this Italian tradition that includes Sorel, although with much less care, see Edmund Jacobitti, Revolutionary Humanism and Historicism in Modern Italy (New Haven, ст: Yale University Press, 1983). More generally, see Paul Piccone, Italian Marxism (Berkeley, CA: University of California Press 1983) and Richard Bellamy, Italian Social Theory (Oxford: Blackwell, 1987), especially chapter four. The main essays from Labriola discussed here were translated into English in the early years of the 2oth century, and are now easily available online. Unfortunately, these translations are not always reliable.

68 Labriola to Croce, 8/12/1894, in Antonio Labriola, Carteggio, ed. Stefano Miccolis, vol. 3 (Napoli: Bibliopolis, 2003), 486. Although the recent volume of work on Croce does not match his importance, see in addition to the works cited above David Roberts, Benedetto Croce and the Uses of Historicism (Berkeley, CA: University of California Press, 1987). Although its focus is political and essentially defensive, an invaluable study is Fabio Fernando Rizi, Benedetto Croce and Italian Fascism (Toronto: University of Toronto Press, 2003). Hughes' Consciousness and Society, cited above, remains a good place to start.

69 Sorel to Croce, 20/12/1895 in Sorel, "Lettere di Georges Sorel a Benedetto Croce," 38. 
which were alive in Italy and which were important in the theoretical reflection of parts of the Italian socialist movement.

As he wrote to Engels in 1894: "With the excuse of being all anti-metaphysical, nowadays Darwin, positivism, Spencer, sociology, socialism ... become one and the same thing." ${ }^{70}$ When seen from this angle, Labriola's long-standing interest in Vico becomes important. As early as 1887 , for example, he had dedicated an entire course in the University of Rome to Vico, presented as the "precursor" of Marx. ${ }^{71}$ In 1895, after having published the above-mentioned essay on the Communist Manifesto in the Devenir social, he wrote in an upbeat mood to Croce, telling him that he might want to write a new piece on Marxism, whose provisional title would have been "From Vico to Morgan."72

This attempt to blend Marxism with ideas from Hegel and Vico was the defining trait of Labriola's work. In a private letter to Engels, he even suggested replacing the word "dialectic" with the more Vichian "genetic method," since this would have left intact "the empirical nature of each specific [historical] formation" as well as, of course, marking the distinction between Marxism and different forms of scientism. ${ }^{73}$ As is to be expected from a Marxism constructed in opposition to late 19th century positivism, Labriola's materialismo storico was essentially an anti-deterministic reading of Marx, which sought to replace the idea of any kind of pre-established laws of historical development with an understanding of Marxism as a theory of human agency, as a filosofia della prassi.

Now, if we look at Labriola's Marxism, a few main elements emerge. Firstly, though it had been brewing since at least the 188 os, Labriola's key theoretical statements all emerged during the period of interaction with Sorel, between 1895 and $1898 .{ }^{74}$ Secondly, its three main tenets—rejection of historical deter-

70 Labriola to Engels, 13/6/1894, in Labriola, Carteggio, 3:413.

71 The sketch of Labriola's University of Rome courses from 1887 to 1894 can be found in a letter he wrote to Croce on 8/12/1894, in Antonio Labriola, Lettere a Benedetto Croce (Napoli: Istituto Italiano per gli Studi Storici, 1975), 6o.

72 Labriola to Croce, $20 / 5 / 1895$, in Labriola, 72.

73 Labriola to Engels, 13/6/1894 in Labriola, Carteggio, 3:412.

74 The three texts are the abovementioned essay in the Devenir social, the volume Antonio Labriola, Del materialismo storico. Delucidazione preliminare (Roma: Loescher, 1896); Antonio Labriola, Discorrendo di socialismo e filosofia. Lettere a Georges Sorel (Roma: Loescher, 1898). In both the drafting and the publishing of these works, Croce and Sorel were decisive - the last of the three works consists, in fact, in a series of fictional letters to Sorel. For a more thorough discussion of the Sorel-Labriola connection, see Tommaso Giordani, "Redefining Historical Materialism in the Peripheries of Marxism: Georges Sorel and Antonio Labriola between France, Italy, and Germany," in Decentering European Intellectual Space, eds. Maria Jalava, Stefan Nygard, and Johan Strang (Leiden: Brill, 2018), 88-113. 
minism, rejection of economicism, and rejection of the understanding of Marxism as a social science - are also the central tenets of Sorel's revisionism.

Thus, Labriola's idea that progress is "always contingent" and "does not hang over human affairs as a destiny, a fate, or as a law" resonates with Sorel's rejection not only of storia ideale, but also of all forms of transcendental explanation of history to be found in Vico. ${ }^{75}$ To Labriola's belief that "attributing preponderance or decisive action to the economic factor" is a misinterpretation of Marxism, a "semi-doctrine," a "mistake" and a "doctrinal error," corresponds Sorel's problematisation of the base/superstructure relation outlined in the previous section. ${ }^{76}$ That Sorel read Vico through Labriola can be confirmed by looking at the short review which he dedicated to the Italian's Del Materialismo Storico in the Devenir social in the late summer of 1896 , a mere month before publishing the first instalment of the "Study on Vico" in October of the same year. ${ }^{77}$

The issues emphasized in Sorel's review are the by now familiar ones: rejection of historical determinism - "progress resembles a zig zag movement more than a regular march following a law" - and of economic determinism. ${ }^{78}$ "Many people," writes Sorel, "believed that Marx's doctrine consisted in simply affirming the decisive action of the economic factor. This manner of reasoning is clearly opposed to the fundamental principle of historical materialism, according to which history forms a unitary complex." ${ }^{\prime 9}$ What's more, in this review we see a combination of Vico, Marx, and Labriola which allows Sorel to formulate for the first time his new social ontology of human agency:

The conception is materialist in the sense that it does not allow the introduction of any ideological explanation ... Things are considered as purely human works, without any intervention on behalf of Providence, or progress, or any formal law regulating [historical] evolution, or teleology: these are all idealistic factors. One applies in the strictest sense Vico's rule: 'The social world is the work of humans', a rule which the author of the New Science combined with a theory of Providence and which Marx has developed in a rigorous manner. ${ }^{80}$

Antonio Labriola, Essais sur la conception matérialiste de l'histoire, 2nd ed. (Paris: Giard et Brière, 1902), 148. Though we are citing from the second edition, the first French edition of this collection dates back to 1897 .

76 Ibid., 154-155.

77 Georges Sorel, “Labriola—Del materialismo storico," Devenir social 2 (1896): 761-766.

78 Ibid., 765 .

79 Ibid., 762 .

8 o Ibid. 
The point is not simply that Sorel read Vico through Labriola. Much more radically, the argument advanced here is that the philosophical backbone of Sorelian revisionism can be understood only in terms of Sorel's combined reading of Marx, Labriola, and Vico. Sorelian revisionism consists in the consequences of a social ontology based on free agency: the rejection of historical and economic determinism, and the reconceptualization of Marxism-and of every form of human thought - as itself an historical product, a form of proletarian self-consciousness. As we have shown, this approach to Marxism not only resolved some conceptual difficulties inherent in Sorel's epistemology but also responded to the constraints and opportunities to which a theoretical Marxist was subjected in the France of the time. In Labriola Sorel found the approach and ideas he needed to develop a theoretically more ambitious Marxism, capable of attempting a dialogue with French social thought.

The dependency of Sorelian revisionism on the ideas of Labriola can be ascertained by examining Sorel's revisionist texts from late 1897 and 1898 and noticing not only the acknowledgment of his debts to Labriola and Croce, but also the fundamental continuity of the arguments deployed, a continuity so strong that it sometimes resembles a paraphrase of Labriola. For example, in an article published in the revisionist Sozialistische Monatshefte, Sorel writes:

Nor do I believe that it is in conformity with a Marxist spirit to decompose facts into various elements: economic ones first, subsequently juridical and political ones ... It is in the form that the distinction can be established, but only for our intellectual necessities; in history, as well as in reason, we have unity; but in order to carry on a scientific study, it is necessary to establish classifications. $^{81}$

This argument against economic determinism essentially suggests that a sphere of economics exists only in the methodological distinctions of the social scientist, but that in historical reality economic activity is always influenced by moral, juridical, cultural, and political factors: it is exactly the same argument made by Labriola. ${ }^{82}$ Examples of this kind could be multiplied. And while it is true that it is only from 1897 onwards that the label "revisionist" begins to have

81 Georges Sorel, "Betrachtungen über die materialistische Geschichtauffassung," Sozialistische Monatshefte 2 (1898), 316-322; 367-375; 428-432. The citation comes from the reworked version printed in Georges Sorel, Saggi di critica del marxismo (Palermo: Sandron, 1903), 42.

82 See Labriola, Essais sur la conception matérialiste de l'histoire, 156-16o. 
a meaning, and that it is only after the opening of the Bernstein controversy that Sorel acts self-consciously as a revisionist and speaks of a "return to Marx," it is also true that the Marxism he articulates in this revisionist period is the same one sketched already in the "Study on Vico."

That Sorel's redescription of Marxism predates the opening of the revisionist controversy and that it heavily relies on Labriola can also be ascertained by noticing the great effort made by Sorel to introduce Labriola in France. Not only did Sorel open the pages of the Devenir social to the Italian theorist, publishing his work and that of Croce as well as reviewing Labriola's Italian work for French readers. More decisively, he pushed for a translation of Labriola's main theoretical works. Sorel wrote a preface for the volume, insisting on the usual points, namely that French understandings of Marxism were way off the mark, and that Labriola shows how Marxism is very distant from notions of historical and economic determinism. The complexity of the relation between economic base and superstructure, stated as a mere fact in the "Study on Vico," is now given theoretical dignity, as Sorel argues that "the mediations that hold between the economic infrastructure and the superior products are variable and cannot be expressed by any general formula." 83

Sorel's operation of implantation of Italian materialismo storico in France failed. Labriola was spectacularly misread by French social thinkers. Both Émile Durkheim and Charles Andler reviewed Labriola's book, and both read it as a statement of classical Marxist economic determinism, despite some very clear indications in the opposite direction present both in the book and in Sorel's preface. ${ }^{84}$ To Andler, for example, it was still a question of "this history of economics, to which Marxism reduces social history." 85 The interpretative grid that French social thought had placed on Marx's work was too rigid, and neither French critic was willing — or possibly able — to see how Labriola was in fact going in a completely different direction. ${ }^{86}$ Sorel's own reading of Vico, together with other factors, would ultimately take him in yet another direction, whichthough not fully subsumable under Labriola's humanist Marxism, remained

83 Georges Sorel, "Préface [1896]," in Essais sur la conception matérialiste de l'histoire, by Antonio Labriola, 1st ed. (Paris: Giard et Brière, 1897).

84 Charles Andler, "La conception matérialiste de l'histoire d'après M. Antonio Labriola," Revue de métaphysique et de morale 5 (1897): 644-658; Émile Durkheim, "La conception matérialiste de l'histoire," Revue philosophique de la France et de l'étranger XLIV (1897): 645-651.

85 Andler, "La conception matérialiste de l' histoire d' après M. Antonio Labriola," 652.

86 On this misreading, see André Tosel, "L'impensé de la sociologie française, ou Labriola lu par Durkheim," La pensée, no. 243 (1985): 98-113. 
nonetheless in continuity with the Italian's perspective. Yet the first moves of Sorel's syndicalism and of his later and more famous writings on social myth are to be found in the "Study on Vico."

\section{5} The "Politics" of the Institution

It is worth offering some clarifications on these last two claims. What kind of politics derived from Sorel's anti-deterministic reading of Marxism? And what is the relationship between Sorel's later syndicalism and the revisionism of the late 189 os?

As for the first question, it is necessary to stress an important conceptual point which, though largely implicit in what has been said so far, does not get an explicit formulation in the "Study on Vico." If we remove historical determinism in all of its guises and if we at the same time reject the notion of a structural economic determination of socio-historical configurations, what remains as the substance of history and as the explanation of historical change? Conceptually, the answer is clear: human agency, or, as Sorel formulated it in his critique of Durkheim, "action considered from the perspective of the agent." But this ontology of the social based on human agency remains extremely vague and is susceptible of many possible theoretical—let alone political—declensions.

Sorel, as should be clear, never conceived of human agency in individualistic terms, but always in collective ones: history is made by groups and not by individuals. Moreover, he never gave to the notion of free agency a promethean reading: even if human agency is ontologically free, this does not mean that patterns, structures, and contingent configurations do not limit the range of action of historical actors. ${ }^{87}$ In other words, he never conceptualised the freedom of human agency in terms of a complete power of re-invention that historical agents would possess vis à vis their situation. Men make their own history, that is, and not only not in circumstances of their choosing, but within material and embodied social reality.

87 Sorel, for example, goes as far as saying that in given circumstances a certain historical complex might develop as if it were completely determined by a given factor, and might even appear as ruled by laws of necessity. This is the case, for example, of capitalist economies in conditions of free market, in which we have relations "which resemble those of the physical sciences." But this determinism is, so to speak, historically contingent: nothing prevents capitalism from going in new and unpredicted directions. See Georges Sorel, "Necessità e fatalismo nel marxismo" [1898], in his Saggi di critica del marxismo (Palermo: Sandron, 1903), 78. 
These clarifications point to a notion which is crucial for Sorel, both theoretically and politically: the notion of "institution." It is only through this notion that Sorel can arrive at a satisfying conceptualization of how human agency deploys itself through history, one capable of safeguarding its creativity without however transcending into pure voluntarism. Seen from a theoretical perspective, institutions are the loci in which the interactions between different historical factors - materiality, consciousness, ideology, morality, economics, and so on-are concretely mediated, connected, and reshaped by human agents.

But institutions have a more interesting political role to play. What is implicit in Sorel's view of history and society is the idea that historical transformations arise from collective subjects, groups who are self-conscious of their historical identity, who are grounded in the conditions of their historical existence, and who have the opportunity of effecting a decisive historical intervention. But how do these historical subjects emerge? The answer lies in the notion of institutions, which provide both the collective dimension and the necessary historical grounding for a new historical subjectivity to emerge. They are the spaces in which new historical subjectivities ripen and develop. It follows that the one goal of Marxist politics must be the institutional development of the proletariat into historical maturity, and that Marxism, in its Sorelian variant, becomes essentially a theory of class. ${ }^{88}$ This emphasis on class developmentthis politics of proletarian subjectivity - is the logical consequence of a revision of Marxism in which historical and economic determinism are rejected, and it constituted the most enduring and fundamental trait of Sorel's politics since the mid-189os. For Sorel, however, this maturation of the proletariat as a class cannot be approached exclusively under the rubric of a disembodied, hopelessly intangible "consciousness." Consciousness must always be thought of in connection to material and social life, and thus cannot exist outside of institutions. ${ }^{89}$

This gives us a more precise idea of the kind of politics which Sorel pursued starting from the late 189os, and which began to appear in rather explicit form in what is arguably his first syndicalist text, the 1898 "Avenir socialiste

88 It is not a coincidence that the title chosen by Sorel for a collection of his Marxist writings published a few years before his death was Matériaux pour une théorie du proletariatMaterials for a theory of the proletariat.

89 Though this is not the place to pursue this point, the term "institution" was widely used in French historical and social science writing of the period. Durkheimian sociology adopted it as the name for the kind of object studied by sociologists. 
des syndicats. ${ }^{90}$ In the analysis of trade unions (syndicats) offered in this text, Sorel is extremely clear on the fact that their function should not merely be that of organising economic conflict against the bourgeoisie. Important as that may be, confining unions to this passive role of resistance means "opposing a formidable barrier to the development of the proletariat; it means delivering it to the overwhelming influence of bourgeois demagogues; it means preventing it from elaborating new principles of right matching its mode of life; it means, in a word, refusing to the proletariat the possibility of becoming a class for itself." ${ }^{\prime 1}$ Unions are instead invested with an active role: they are the institutions in which the proletariat tests, harbours, and develops new forms of social life. These new social relations can be, for example, juridical, but are by no means limited to this legal dimension. ${ }^{92}$ They include new principles of political organisation, new modes of production, and even new kinds of kinds of sexual and sentimental arrangements. Unions are, in short, a socialist society gradually developing inside the context of bourgeois capitalism:

[Unions] will thus eventually manage to deprive of all life old social forms ... leaving them only to administer repulsive functions of surveillance and repression. At that point, a new society will have emerged, based on completely new elements and on purely proletarian principles. ${ }^{93}$

But what does a politics of class development concretely look like? Two political imperatives derive from this commitment to institutional development: a certain understanding of the revolutionary process and a call for class separation. As for the first point, it is important to notice the type of transition to socialism which this vision presupposes: a slow, gradual, longue durée process of historical transformation in which new forms of human sociability begin emerging already in the context of the old bourgeois order. This gradualist understanding of the road to socialism has clear political implications, because it amounts to an uncompromising rejection of insurrectionary solutions. Already in the "Study on Vico" Sorel had warned that the socialist revolution would not be "a war of extermination ... baying for the destruction

$90 \quad$ Georges Sorel, "L' avenir socialiste des syndicats," L'humanité nouvelle 2 (1898): 294-307; 432-445.

91 Ibid., 435 .

92 When the legal principle of collective bargaining is recognized, Sorel argues, we have a juridical victory for the proletariat, who has created "a system of new rights ... through struggles and countless difficulties." Ibid., 433.

Ibid., 441. 
of worldly things and breaking abruptly with the past." In the "Avenir," this anti-insurrectionist stance is confirmed. The socialist struggle, writes Sorel, "is not a struggle to conquer the positions occupied by the bourgeois and revel in the spoils; it is a struggle to empty the bourgeois political organism of all life and to transfer everything useful it contained into a proletarian political organism, forged gradually through the development of the proletariat." 94

Though aversion to revolutionary insurrection was typical of late 19th century Marxism, it must be underlined how, for Sorel, it is deeply connected to the rejection of economic determinism and, more generally, to his understanding of the social world as a complex and essentially unstable web of interactions between social spheres which can be separated only artificially. In other words, if the transition to socialism, as any large historical transformation, is a question of slowly developing new social relations within new institutions, then it appears clear that no seizure of power, no insurrection, no coup d'état can ever yield a transformation of this magnitude. Neither a Marxist Zusammenbruch of capitalism nor anarchist insurrection are, for Sorel plausible at this point.

A second way in which Sorel gave more substance to what we have called the politics of proletarian subjectivity is the injunction to class separatism. The "Avenir" contains a large section dedicated to the damage that bourgeois intellectuals do to the working class movement, exploiting the "superstitious respect which the people instinctively have for science."95 The argument outlined in the text touches upon the infantilization which working people have to suffer at the hands of bourgeois socialist leaders and ends up insisting on the usual point, namely that tutelage is antithetical to class development: "if the worker accepts the leadership of people alien to the productive community, he will always remain incapable of self-government." ${ }^{\prime 9}$

This, again, is completely in line with the theory of proletarian institutional development: new social forms are developed in new institutions, but in order to be new, these institutions must be grounded in a substantially new historical experience, which is that of productive activity in modern capitalist factories. The argument against class collaboration, in other words, is not really one about political expediency, but touches a much deeper level of Sorel's reasoning. If the proletarian roots of the new institutions are compromised, then

94 Ibid.

95 Ibid., 302.

96 Ibid., 305-3o6. 
the entire work of class development, and hence the entirety of the socialist project, is at risk. Hence the closing words of the "Avenir," which exhort unions to "remain exclusively working class."

It must be added, however, that the connection between a theoretico-philosophical position and a political one is never straightforward, and in this case appears particularly loose. Though a number of "political" positions can be said to derive from Sorelian revisionism, the extent to which these positions can genuinely be called political is debatable, in that they remain at a high level of generality and are not specific enough to commit Sorel to a choice between actually existing political options.

Take, for example, the insistence on class separation, which one would think would commit Sorel to anti-parliamentarianism and isolationism. And yet, in the pages of the "Avenir" we read that the proletariat "must enter the struggle under the present conditions of political organisation, in order to obtain social legislation favourable to its development"-an endorsement of parliamentary reformism..$^{98}$ Reformism and parliamentarism are, in fact, the political options which Sorel will support until 1902, believing that the most effective way to ensure the institutional development of the proletariat is that of securing, through parliamentary means, reforms which can grant to the proletariat greater resources to build its autonomous institutions.

The point being made here is not that there is a contradiction between the politics of institutional development and Sorel's reformism: it is the exact opposite, namely that there is no contradiction. As Marco Gervasoni convincingly argues:

Sorel did [in the late 189os] theorize an original position on the question of the relationship between the workers' movement and democracy. If proletarian institutions could participate and claim as their own the social reforms put forward by governments, they still needed to remain independent from political influences; they were allowed sympathizers in Parliament, but they could not unite stably and structurally with the parties that operated in Parliament, or, even worse, accept the direction of the State under any form. ${ }^{99}$

The point which is being made is that Sorel's politically vague and theoreticallyinformed commitment to proletarian institutional development is politically

97 Ibid., 445 .

98 Ibid., 444.

99 Gervasoni, Sorel, 163. 
underdetermined. It is compatible with a vast range of mutually exclusive political options, from parliamentarism to more contentious stances. The concrete direction in which the imperative of proletarian class development is pursued depends on a series of judgements and evaluations which are eminently contingent and, above all, political. Synthetically, they can be reduced to the following set of questions. Is it possible to engage in parliamentarism and electoralism without compromising the autonomy of proletarian institutions? Is a purely instrumental involvement in the democratic state possible, or is it a practice which inevitably leads to the abandonment of the politics of proletarian institutional development? Is, in short, democracy compatible with revolutionary institution building or are the two antithetical?

The different answers which Sorel gave to these questions determine two different phases of his political life and explain the change from the reformism of the late 1890 s to the revolutionary syndicalism which he embraced from 1902. In the late 189os, the answers are overwhelmingly positive: we see Sorel siding with Jean Jaurès against Jules Guesde, accusing the old guard of the Parti Ouvrier of abstract dogmatism, and suggesting that "workers are much more interested in practical reforms than they are in theories," i.e. prefer the small victories of the parliamentary wing to the doctrinal dogmatism of the Guesdists. ${ }^{100}$ Beginning after 1902, the answers are negative, and bring Sorel to believe that the greatest danger to the workers' movement is represented precisely by the democratic involvement which he had championed a few years earlier.

The reasons for this shift on the question of the compatibility between parliamentarism and socialism have to do with a disillusionment with the republican victory in the political crisis which followed the Dreyfus affair as well as, more importantly, with a completely new analysis of welfare capitalism. ${ }^{101} \mathrm{But}$ for our present purposes they are somewhat beside the point. What matters is that the shift was eminently political and did not touch the bases of Sorelian revisionism. Parliamentary reformism and revolutionary syndicalism were, in other words, two possible political declensions of Sorel's vague commitment to proletarian institutional development, both equally compatible with the revision of Marxism operated by Sorel in the mid-189os. Though theoretically rich and original, Sorelian revisionism remained politically underdetermined and substantially unaltered after its first formulation.

100 Georges Sorel, "L'evoluzione del socialismo in Francia," La riforma sociale 9 (1899): 518.

101 Georges Sorel, Insegnamenti sociali dell'economia contemporanea. Degenerazione capitalista e degenerazione socialista (Palermo: Sandron, 1907). 
The Reflections on Violence was a book chiefly concerned with the existential threat Sorel thought parliamentarism and social legislation posed to the class identity of the proletariat. The core of Sorel's proposal in this text-what he calls grève prolétarienne - is neither a desperate ode to violence nor an illconceived insurrectionary strategy. It is, instead, a mildly violent and highly ideological practice of social conflict which for Sorel could potentially overturn the rising tide of welfare capitalism, an economic environment which falsified the standard Marxist analysis of capitalist development in terms of social polarization. ${ }^{102}$ Socialism itself could come not through violence, but only through a process of proletarian institutional development. What violence could yield was restoration of the class structure, confinement of the bourgeoisie to their "role as producers," and return to a capitalist society marked by class enmity. Those conditions were desirable because they permitted genuinely proletarian institutions to thrive and expand. ${ }^{103}$

What marks the Reflections on Violence most decisively, however, is the attention given to the capacity of a specific kind of violence to reconfigure the ideological field. The principal way in which, for Sorel, violence can "restore the class structure" is by acting upon collective consciousness, both bourgeois and proletarian. The text of the Reflections is punctuated by constant allusions to the "educational" or "ideological" function that violence can have. But in order to be able to perform this function, violence requires an additional element: it must be understood, experienced, and narrated through the lenses of a social myth.

Together with violence, myth is the term most associated to Sorel. Myth took on theoretical dignity in the pages of the Reflections and was decisive to nationalist readings of Sorel during the interwar. In the final pages of his 1923 Crisis of Parliamentary Democracy, Carl Schmitt discusses the notion and quotes Benito Mussolini's speech in Naples from the year before to show that Sorel was wrong. Though myths are important, the proletarian general strike is an out-

\footnotetext{
102 Sorel was of course not the only one who understood the challenges that new economic developments, along with new modes of governance of these developments, posed to the standard Marxian analysis. His reasoning on these issues should be contextualised in the wider framework of the crisis of Marxism of the turn of the century. See Eduard Bernstein, The preconditions of socialism [1898], ed. and trans. Henry Tudor (Cambridge: Cambridge University Press, 1993), as well as the more comprehensive Henry Tudor and J.M. Tudor, eds., Marxism and Social Democracy. The Revisionist Debate 1896-1898, trans. Henry Tudor and J.M. Tudor (Cambridge: Cambridge University Press, 1988).

103 Sorel, Reflections on Violence, 78.
} 
dated one, since when myths "occur in the modern period, the stronger myth is national." 104 In his speech in the San Carlo Opera Theatre, Benito Mussolini had, a mere three days before the March on Rome, indeed spoken on the importance of myths:

We have created our own myth. That myth is a faith, it is a passion. It isn't necessary that it be a reality. It is a reality by virtue of the fact that it is a fist, that it is a hope, that it is a faith, that it is courage. Our myth is the nation, our myth is the greatness of the nation!105

The Sorelian influence is evident. In the "Letter to Daniel Halévy" that serves as an introduction to the Reflections, Sorel had, in 1907, written that "myths are not descriptions of things, but expressions of will."106 Many chapters later, he had insisted that "it matters little whether the general strike is a partial reality or simply a product of the popular imagination." ${ }^{107}$ The examples of myths offered by Sorel-ranging from the glory of the Napoleonic Grande Armée to the transcendental significance attributed by the first Christians to their martyrdomfurther make it clear that there is no necessary connection between myths and the proletariat. Myths occur throughout history and are not exclusive to the proletariat.

If we add that for Sorel "people who are living in this world of myths are secure from all refutation," we can see how the Sorelian myth came to be understood as a deeply held conviction or dream that was invulnerable to rational examination. ${ }^{108}$ Factoring in Mussolini's effective political adaptations, we understand how the Sorelian notion of myth could be seen as an early draft of fascist or totalitarian propaganda. Disdain for parliamentary democracy, preference for emotive language, enthusiasm for violence-here is Sorel as protofascist. 109

104 Carl Schmitt, The Crisis of Parliamentary Democracy [1923], trans. Ellen Kennedy (Cambridge, MA: MIT University Press, 1988), 74-75.

105 Benito Mussolini, "Speech to San Carlo Opera Theatre, Naples, 25/10/1922," in Mediterranean Fascism (1919-1945), ed. Charles F. Delzell (New York: Macmillan, 1970), 42.

106 Sorel, Reflections on Violence, 28. Translation modified. The original French reads, "ce ne sont pas des descriptions de choses, mais des expressions de volonté." Jennings' edition reads "will to act." T.E. Hulme's first translation gives "expressions of a determination to act."

107 Ibid., 117.

108 Ibid., 30.

109 It is thus natural that myth has been a central focus of work on Sorel. In French, Willy Gianinazzi, Naissance du mythe moderne. Georges Sorel et la crise de la pensée savante 
And yet, the myth that interested Sorel was an "image" or an "idea" which "contains within itself the whole of proletarian socialism." 110 Myths could be described as the psychological, ideological, and emotional conditions that emerge from a self-conscious group of people when engaging in social conflict. The metaphorics with which Sorel illustrates the notion of myth in the Reflections are depth versus surface, movement versus stasis, image versus language. The terms are self-consciously Bergsonian. ${ }^{111}$ Yet there are good reasons to doubt the importance of Bergsonian notions to Sorel's argument. One is that most of the references to Bergson did not appear in the earliest Italian versions of texts that would become the Reflections, but were added for publication in French. ${ }^{112}$ Though Bergson is certainly important for Sorel more broadly, this introduction has shown that the study of social and political psychology has much deeper roots in Sorel's work.

Indeed, Sorel's thinking on myth is recognizably drawn from Vico's approach to the myths of antiquity as evidence of social reality. For instance, according to Vico the god Hermes comes to stand for a whole range of phenomena. The primitive imagination has its own logic and reduces a "totality" of relations into a compact image. Sorel quotes Vico, "these vast imaginations ... curled themselves up and were indicated by the smallest signs."113 A decade later, he would write that revolutionary syndicalism "concentrate[ed] the whole of socialism in the drama of the general strike," constituting into myth these "images" which then had then to be taken as a whole and could not be disaggregated without destroying something essential about their social function. ${ }^{114}$ If Sorel was eager

(Paris: Éditions de la Maison des Sciences de l'Homme, 2006) is the most significant contemporary work here. See also Willy Gianinazzi, "Images mentales et mythe social. Psychologie et politique chez Georges Sorel," Mil neuf cent 28 (2010): 155-172; Éric Michaud, "Le mythe social ou l'efficacité de l' image sans images," Mil neuf cent. 28 (2010): 173-183. Sorelian myth has recently been the subject of but interesting but scattered Anglophone scholarship. See Mark Antliff, "Bad Anarchism: Aestheticized Mythmaking and the Legacy of Georges Sorel," Anarchist Developments in Cultural Studies, no. 2 (2011): 155-187; Tudor Balinisteanu, "Spellbinding Stories. Gender Theory and Georges Sorel's Concept of Social Myth," Critique 42, no. 1 (2014): 107-126; Chiara Bottici, "Philosophies of Political Myth, a Comparative Look Backwards: Cassirer, Sorel, and Spinoza," European Journal of Political Theory 8, no. 3 (2009): 365-382.

110 Sorel, Reflections on Violence, 15 o.

111 Ibid., 26, 29, 118.

112 Tommaso Giordani, "On Sorel and Bergson. The Impact of Bergsonian Ideas on Sorel's Reflections on Violence," Lo Sguardo — Rivista di filosofia 26, no. 1 (2018): 163-181.

113 See translation below [1022] and $\S 402$.

114 Sorel, Reflections on Violence, 113. 
to see the proletarian barbarians at the gate, he tried to understand their incipient civilization by looking to Vico's reconstruction of the heroic mind.

Close to a theory of ideology, Sorel's notion of myth was partially developed to explain the gap between the dwindling empirical validity of certain Marxist predictions and their evident traction in the working class. ${ }^{115}$ To proclaim the falsity of Marxism and label the working class confused obviously would not do. Myths, rather, Sorel came to argue following Vico, represent condensations of the conditions of life in certain sections of society. But Sorel points out, "it is not things that are assimilated, but actions." ${ }^{116}$ Hence, myths also contain the aspirations and ambitions of the social group which creates them. A myth "is, at bottom, identical to the convictions of a group, being the expression of these convictions in the language of movement." 117 There is no space here for an account of the development of myth in Sorel's writings, and we are not claiming that Sorel's idea of myth was fully formed in 1896. Quite the contrary. We are, however, arguing that if we wish to understand the historical beginnings of this influential Sorelian notion, we will need to look first to the "Study on Vico," and then follow its lead into the twentieth century, including the years after Sorel's death.

\section{7}

Beyond Syndicalism

To conclude this introduction, it is necessary to give a very summary outline of Sorel's developments after the publication of the Reflections on Violence: this will not only show the enduring relevance of the issues at the heart of the "Study on Vico," but also offer a somewhat different biographical portrait of the man widely reputed to have been a fascist avant la lettre. It must, however, be said that this period contains no important theoretical evolutions: the philosophical and epistemological positions which Sorel had reached in

115 Some of these dilemmas arrive for Sorel quite quickly. Already in 1898 , he writes (for an Italian audience) on the "crisis" and "decomposition" of Marxism, which was proving unable to mediate between its claims to scientificity and the demand of actually mobilizing political power. Genuine and necessary reforms, Sorel wrote, are not made simply on the basis of science. "Our mind needs poetry in order to resolve the heart into action," he wrote, but it easy and dangerous to get carried away, "the socialists must not, through sheer imagination, finish by dreaming up a sociological mythology rather than observing the facts." Georges Sorel, "La crisi del socialismo scientfico," Critica sociale 8, no. 9 (May 1, 1898): 138 .

116 See translation below [1022] and §402.

117 Sorel, Reflections on Violence, 29. 
the period between 1896 and 1898 will remain fixed and will only be reformulated through the aid of new philosophical vocabularies, including Bergsonism and Pragmatism. It is, nonetheless, a period which is of a wider historical interest, because in the years after 1906 Sorel will be confronted by the defeat of revolutionary syndicalism, the Great War, and the Bolshevik revolution.

As we have seen, for Sorel the question of safeguarding the class identity of the proletariat was, to a substantial extent, a question of class consciousness and ideology. It is in the context of this project of ideological intervention that we should situate a book which came out virtually simultaneously to the Reflections, the Illusions of Progress. With the exception of an article on Rousseau, this is the text in which Sorel deals most systematically with the legacy of the Enlightenment. ${ }^{118}$ The work is to be understood both as an exercise in the social history of ideas and as a political intervention attempting a critique of republican ideology: in both of these aspects, the indebtedness to the insights first developed in the "Study on Vico" is evident.

As a work of intellectual history, Sorel makes it clear in the preface that he is following the Marxism first outlined "over ten years ago" by Antonio Labriola, and insists on the sterility of Marxian analyses based exclusively on economic determinism. ${ }^{119}$ As a political intervention, the aspect to underline more forcefully is not so much the uses which the Third Republic had made of the philosophy of the 18th century, as much as Sorel's belief that the historical critique of ideas is an important part of political struggle. This is something in continuity with the importance which he had attributed since the mid-189os to questions of ideology, collective psychology, and class consciousness.

The years after the publications of these two books are years of disillusionment for Sorel, coinciding with the political defeat of the revolutionary syndicalists in the CGT, which had gained control of the organization in 1906. The defeat of the syndicalists, broken by the repression of the state in a series of strikes, flew, moreover, in the face of Sorel's argument in the Reflections on Violence: a more contentious stance had not determined the defeat of parliamentarism and social legislation, but merely a military and eventually political defeat of those who had challenged the republic. ${ }^{120}$

\footnotetext{
118 Georges Sorel, "Jean-Jacques Rousseau," Le mouvement socialiste 21 (1907): 507-532.

119 Georges Sorel, The Illusions of Progress, trans. John Stanley (Berkeley: University of California Press, 1969), xl-xli.

120 On the events of 1907-1908 and the defeat of the syndicalists see Jacques Julliard, Clemenceau briseur de grèves. L'affaire de Draveil-Villeneuve-Saint-Georges. (Paris: Gallimard, 1973).
} 
In the first weeks of the decisive strike of Draveil-Villeneuve-Saint-Georges, he published an article in Le Matin, one of France's largest daily newspapers, whose telling subtitle was hors la grève, pas de socialisme (no socialism without strikes). In it Sorel—introduced to the public as someone who "renounced his bourgeois career to consecrate himself to the social revolution"-lauded the heroism of the strikers, comparing them to those Napoleonic soldiers who "accomplished so many acts of valour, knowing all the time they would remain poor." Plausibly sensing the impending defeat, he added, "What remains of the Empire? Nothing but the epic of the Grande Armée; what will remain of the present socialist movement will be the epic of the strikes."121

Readers will recognize in this fetishism of the struggle and of the glory it brings the familiar historiographical Sorel. And yet, even a modicum of contextualisation suggests caution: written a few weeks before the decisive defeat of the syndicalists at the hand of the French Republic, these words should not be read as the expression of the most fundamental tendencies of Sorel's social and historical thought. A year later, the syndicalists' defeat now firmly established, he will publish an article in the Italian Il Divenire sociale in which the world-historical language of grandeur and decadence is used to talk about the failure of the syndicalist project, and in which the clash between proletarians and bourgeois is rendered as a clash between greatness and mediocrity. ${ }^{122}$ These are the years in which Sorel's rhetorical hostility against the Republic is arguably at its peak, and they are also the years in which he gets close to the monarchist and antisemitic Action française. His debut for Maurras' group is in an interview given to their daily newspaper, where he is presented as someone who "in virtue of his past politics, would appear as belonging to the extreme left," but whose "independence of judgement and character" allows him to be taken seriously by the royalists. ${ }^{123}$

It is undeniable that Sorel lent himself to the attempt of the Action française to proselytize amongst the remnants of a defeated syndicalism, as not only he occasionally wrote for their publications, but also collaborated more assiduously in a journal established together with younger royalists, the Indépendance. And yet, neither the extent nor the significance of these episodes

\footnotetext{
121 Georges Sorel, “Apologie de la violence," Le Matin, May 18, 1908.

122 Georges Sorel, "Evoluzione e decadenza," Il Divenire sociale 5 (1909): 16-31, 272-275, 283285 and Il Divenire sociale 6 (1910): $24-27,47-49,55^{-56}$. The text will be published in French in 1910 as an appendix to the second edition of the Illusions of Progress under the amended title "Grandeur et decadence."

123 Léon Daudet, "Une conversation avec M. Sorel—Ferrer et Briand," L'Action française, September 29, 1909 .
} 
should be exaggerated. Sorel published only four pieces in the Action française. ${ }^{124}$ There where, admittedly, two projects to create publications attempting a synthesis between syndicalism and royalism - the failed Cité Française in 1910 and the more successful Indépendance the following year-Sorel's collaboration was not entirely transitory. However, writing to Croce about the prospect of entering such a project, Sorel had confessed, "It is a terribly burdensome task for me, given my health conditions; but I have accepted on condition that [Edouard] Berth be the co-director; in this way, if the enterprise proves successful, I will be able to withdraw and leave Berth in a comfortable position."125 The reasons which brought Sorel to these collaborations have to be searched for not only in his break from the Mouvement socialiste, but also in a virulent opposition to the republic which he shared with the royalists. As Jeremy Jennings argues, the defeat of the syndicalists left Sorel in the position of having to mount "a total attack on bourgeois society, its political structures, and its moral and cultural values. It was this virulent critique that brought him into contact with the forces of the extreme Right and which, indirectly, led amongst some of his admirers to the fusion of Sorelian doctrine and nationalism."126

In short, though Sorel certainly collaborated with nationalists, he was never himself a nationalist. Not even the nationalistic frenzy of the Great War could bring this out in him. Though his production dropped throughout the warhe published nothing between 1916 and 1919 - the tone of this 1914 letter to Benedetto Croce is sufficiently clear:

124 Besides the above-mentioned interview, the other three pieces are a republication of a political article originally written in 1907 for the Divenire sociale (Georges Sorel, "Socialistes antiparlementaires," L'Action française, 22 August 1909), a republication a review of Charles Péguy's Le mystère de la charité de Jeanne d'Arc originally written for the Florentine journal La Voce (Georges Sorel, "Le réveil de l'âme française," L'Action française, 14 April 1910) and a letter offering further comment to that review (Georges Sorel, "Une lettre de Georges Sorel," L'Action française, 6 June 1910).

125 Letter to Benedetto Croce, 28/6/1910 in "Lettere di Georges Sorel a Benedetto Croce," La Critica 26 (1928): 341. Edouard Berth (1875-1939) was one of Sorel's closest followers. He pursued, much more thoroughly than Sorel, the project of uniting syndicalism with nationalism. In collaboration with Georges Valois (real name Alfred-Georges Gressent) and under Charles Maurras' aegis, Berth would establish the Cahiers du Cercle Proudhon, a journal which, for its two years of existence between 1911 and 1913, proposed a nationalist variation on Sorelian themes. Sorel never wrote for this publication, and its strongest connection with Sorel lies in its fierce critique of bourgeois society and its democratic institutions. Valois went on to establish the Faisceau, a French imitation of Mussolini's party, before returning to the left and dying as a captured resistant in Bergen-Belsen. Berth, on the other hand, remained by his own account on the left his whole life.

126 Jennings, Georges Sorel, 158. 
Like many others, I quit my home, following the advice of the authorities ... The events overwhelm me: I feel that we are entering an era more modern than that of the Revolution ... Old Prussia, which felt itself being absorbed into the new industrial Germany seems to me to be wanting to die in the middle of rivers of blood; we shall witness something similar to the Judean war: who will be the poet, the historian or the philosopher of this terrifying catastrophe? [...] I am a man of the past, I have nothing left to say to men who will be able to loudly affirm their Jacobin principles; it seems to me that Proudhon, in his last years of life, had similar impressions to the ones I have now: you are younger and you will be able to formulate the philosophy of the new revolution. ${ }^{127}$

Unlike many other French intellectuals who joined the nationalist effortsome in flesh, like Charles Péguy, some in pen, like Henri Bergson-Sorel never saw anything else in the carnage but the total defeat of his ideas and the triumph of "Jacobin" bourgeois democracy. "Those of us who think that we have entered an era independent from Jacobinism" he wrote in 1914 to Agostino Lanzillo "are finished. The best we can do is to work on problems which have nothing to do with social questions." ${ }^{128}$

After a protracted wartime silence, however, Sorel will lose this gloom and come back not only to publishing, but also to political writing, and even to socialism. In 1919, he will publish a collection of his socialist writings, the abovementioned Matériaux d'une théorie du proletariat. The dedication of the book read: "May my dear comrades Paul and Leona Delesalle accept the homage of this book, written by an old man who stubbornly remains, like Proudhon, a disinterested servant of the proletariat." ${ }^{129}$ The reason for Sorel's newfound energy and faith in the socialist cause is very easy to guess: the Bolshevik revolution and the revolutionary wave which was sweeping Europe from Germany to Hungary to Italy. Having lost most of his savings in defaulted Russian bonds, Sorel was moreover forced now to write for a living, something which he managed to do by becoming a columnist for the Italian newspapers Il Resto del Carlino and Il Tempo. It is mostly from the columns of these newspapers, and mostly

\footnotetext{
127 Letter to Benedetto Croce, 22/9/1914, in "Lettere di Georges Sorel a Benedetto Croce," $L a$ Critica 27 (1929): 51 .

128 Letter to Agostino Lanzillo, 23/10/1914, in Cher camarade, 210.

129 Georges Sorel, Matériaux d'une théorie du prolétariat (Paris: Marcel Rivière, 1919). Paul and Leona Delesalle, beyond being personal friends of Sorel, were anarcho-syndicalist militants of a certain relevance. See Jean Maitron, Paul Delesalle. Un anarchiste de la belle époque (Paris: Fayard, 1985).
} 
for the Italian public, that in the last years of his life he agitated in favour of Lenin and the Bolsheviks. Thus, in the beginning of the biennio rosso, after a quasi-insurrectionary general strike in the summer of 1919, and at the opening of the Bologna congress of the PSI (Partito Socialista Italiano), Sorel intervened in favour of the radical (massimalista) wing of the party with an article in the Resto del Carlino:

Bolshevik legislation offers us a pragmatic translation of communism: it has instituted councils of control over factories which are nominated only by workers. When workers, instead of asking Kautsky and his friends for a blueprint, go through their industrial education by having greater powers inside factories, they are doing their work as communists! The experience which is being had in the FIAT factories [at the time occupied by workers] ... is more important than all the writings published in the Neue Zeit! $!^{130}$

Sorel's infatuation for the Bolsheviks, as we can see, has many layers. The institution of the soviets appeared to him as a realization of his old syndicalist vision: an autonomous, self-governing, proletariat who takes control of production and develops administrative and juridical capacities. Moreover, even if not yet successful in Italy, this institution had certainly triumphed in Russia, discrediting with its victory decades of social-democratic experience and leadership of the working class by parties. Finally, this infatuation was not merely the romantic revolutionary mirage of an old man, but involved, as this article shows, active intervention in concrete politics, albeit not in France. If we compare the amount of work and interest which Sorel dedicated to the Bolsheviks to the almost complete indifference he reserved for Italian fascists, the idea of Sorel as a supporter of both Lenin and Mussolini appears, euphemistically, implausible. ${ }^{131}$

A final point worth mentioning is the return, in the years after the Great War, to serious work on questions of epistemology and the philosophy of science: a mere year before his death, Sorel will publish what is arguably his most systematic work of philosophy, a long tome entitled De l'utilité du pragmatisme.

\footnotetext{
130 Georges Sorel, "Il massimalismo italiano. Ai miei compagni d'Italia," Il Resto del Carlino, October 5,1919 .

131 The only source which attributes to Sorel sympathies for Mussolini's fascists in the immediate postwar is Jean Variot, Propos de Georges Sorel recueillis par Jean Variot (Paris: Gallimard, 1935), but it is a highly suspicious one. Variot was involved with Sorel in the project of the Indépendance and was a militant royalist. Moreover, these memories were published 13 years after Sorel's death, and clash quite strongly with Sorel's writings of 1919-1922, overwhelmingly concerned with Russia and with the possibility of social revolution in Italy.
} 
American pragmatism was a philosophy that Sorel, like many other French intellectuals, had discovered starting from 1906, when a series of translations and discussions of the work of William James had entered French intellectual life. Initially suspicious of this philosophy, Sorel had gradually changed his mind, coming to see in the pragmatist theory of truth a philosophical argument very much in line with his long-standing concern to make science "descend towards the concrete."132 Utilité du pragmatisme not only represents a return to the conceptual problems which had been central to the "Study on Vico" - the epistemic nature and the limits of scientific claims, the relationship between practical activity and abstract thought, the extent to and mode in which science is to be considered an historical product - but constitutes the most radical restatement of the historicist theses which Sorel had started formulating as early as the late 1880s. "The only truthful element in the history of sciences" he claims in this last book "is artificial nature."133

\section{$8 \quad$ Conclusion}

The "Study on Vico" which follows in English translation ought to be read within the contexts which we have outlined in this introduction. The most general framework through which Sorel approached Vico was that of his ongoing concern for the epistemology of the sciences, both social and natural. It was this concern which had led him to the discovery and embrace of Marxism. The difficulties which had plagued Sorel's previous epistemological work were not resolved by Marx, but by Vico's principle of verum ipsum factum, which Sorel read back into Marx. Before the encounter with Vico, Sorel had oscillated between historicist stances-insisting on the historicity and artificiality of scientific practice - and neo-Kantianism, i.e. the belief that scientific explanation required causality, necessity, and some form of determinism.

With verum ipsum factum, Sorel abandoned neo-Kantianism and increasingly moved in a historicist direction, towards an ontology of the social world as marked by human agency. Vico himself had organized this agency according to "nation" and divine Providence. Sorel dropped Providence and disaggregated the nation into the class and the institution, each liable to the processes of development recognized by Vico. From scientific theories to moral systems,

132 Georges Sorel, De l'utilité du pragmatisme (Paris: Marcel Rivière, 1921), 342. For a summary overview of Sorel's pragmatism see Tommaso Giordani, "Introduction au pragmatisme de Georges Sorel," Mil neuf cent 32 (2014): 93-110.

133 Sorel, Utilité du pragmatisme, 35 o. 
from economic transformations to political revolutions, everything now had to be understood as human production, as the fruit of human creativity deployed in given historical conditions. Only an epistemological principle like Vico's could allow him to make this move. This philosophical commitment to historicity and human agency is what allows us to explain Sorel's later philosophical interest in pragmatism.

But the "Study on Vico," as we have shown, also represents the turning point of Sorel's engagement with Marxism. Insofar as Sorel's commitment to Marxism was of a scientific kind, there is a clear connection with the epistemological break outlined above. From the "Study on Vico" onwards, Sorel ceased seeing Marxism as science rationelle, as a social science capable of unearthing fundamental historical necessities. These historical necessities were now a conceptual impossibility — history was made by human agency—although perhaps they remained psychologically essential. Thus, it is in this text which we can see the first formulations of the fundamental tenets of Sorelian Marxism: the rejection of economic determinism, the rejection of historical determinism, and the understanding of Marxism as a form of proletarian self-consciousness.

Politically speaking, Sorelian revisionism implied a commitment to the development of proletarian historical subjectivity, an issue which is merely alluded to in the "Study on Vico" - when Sorel speaks of the proletariat's acquisition of the "consciousness of its historical role" as one of the conditions for socialism - but which will be developed more thoroughly a couple of years later in the "Avenir Socialiste des Syndicats." It implied, moreover, a rejection of a conception of the revolution as insurrection: far from a "Jacobin" seizure of power, socialism will be the result of a long historical process involving economic transformation and, most importantly, the development of a new historical subjectivity, that of the proletariat. And yet, though this revisionism gave these two political imperatives to Sorel, it still remained politically underdetermined and reconcilable with a large number of mutually exclusive political positions. What ensures the growth of proletarian institutions in the present context? To this question, Sorel gave different answers, and these answers help us understand his transition from instrumental reformism to revolutionary syndicalism.

What should be underlined by way of conclusion is how this commitment to proletarian institutional development is the logical consequence of a very particular understanding of Marxism. Profoundly alien to any form of base/superstructure way of thinking, the Marxism elaborated by Sorel through Vico and Labriola is, philosophically, rooted in a full commitment to historicity conceived as collective human agency. Since this agency is fundamentally creative, it requires the abandonment of both historical and, perhaps more importantly, 
economic determinism. It is a good indication of the misreading of this thinker that Martin Jay should describe Sorel's view of Vico as "the anticipator of Marx's contention that ideas were epiphenomena of material forces embodied in the mode of production."134

For though Sorel in the "Study on Vico" does indeed use the term "epiphenomena," it is to say that "moral valuations" are not epiphenomenal but rather play a "capital role" in the historical process. As we have amply shown, for Sorel and for Labriola "materialism" is not to be interpreted in terms of a determination of material factors upon ideal ones. Instead, it is a commitment to historical immanence and to an ontology of the social world and of history in terms of human creative agency. If this argument is accepted, there is space for a rethinking of Sorel in terms of an important pre-war instance of a tradition of thought that has been called humanist Marxism. The Italian roots of Sorel's Marxism - the same roots which later nourished the thought of Antonio Gramsci-seem to indicate the appropriateness of this hypothesis.

134 Jay, Fin de Siècle Socialism, 49. 